\title{
Progressive proglacial to subglacial deformation and syntectonic sedimentation at the margins of the Mid-Pleistocene British Ice Sheet: evidence from north Norfolk, UK.
}

Emrys Phillips ${ }^{1 *}$, Jonathan R. Lee ${ }^{2,3}$, Helen Burke ${ }^{2}$

${ }^{1}$ British Geological Survey, Murchison House, West Mains Road, Edinburgh EH9 3LA, Scotland, UK

${ }^{2}$ British Geological Survey, Keyworth, Nottingham, NG12 5GG, UK

${ }^{3}$ Department of Geography, Royal Holloway, University of London, Egham, Surrey, TW20 0EX, UK.

* corresponding author

telephone: +44 (0)131-667-1000 fax: +44 (0)131-668-2683 e-mail: erp@bgs.ac.uk

\begin{abstract}
Detailed analysis and interpretation of the stratigraphy and structures developed within polydeformed sediments exposed in the coastal section between West Runton and Sheringham (eastern England) has allowed the characterisation of the glacitectonic signature associated with the advance of a major Mid-Pleistocene (Anglian) ice sheet. The sequence of pre-glacial deposits and glacial sediments laid-down during earlier southerly directed ice advances (D1-D2) are deformed and disrupted by an ice advance from the west/southwest that marks a major change in ice flow dynamics in northern East Anglia. The simplest interpretation of this deformation event (D3) is in terms of a progressive proglacial to subglacial deformation model. Proglacial deformation occurred in-advance of the ice margin and was dominated by thrusting. Positive topographic features which developed above the propagating thrusts controlled sediment dispersal patterns within outwash sandur, leading to the formation of small sub-basins between these morainic ridges. The accretion of the wedgeshaped, proglacial thrust moraines to the main push moraine formed at the margin of the advancing glacier may have temporarily stalled forward motion of the ice. Thrusting and large-scale folding associated with ice-marginal deformation led to the stacking of material excavated from further up-ice onto the stoss-side of these accreted thrust-related moraines that allowed the glacier to override the obstruction. Subglacial deformation was highly variable in its style and intensity ranging from heterogeneous folding and thrusting, through to more pervasive ductile shearing associated with the formation of a subglacial shear zone. The
\end{abstract}


thickness and complexity of this shear zone increases up-ice, where it is characterised by a thick glacitectonic mélange. The pore water content of the deforming sediments controlled the pattern of deformation within the shear zone. However, an increase in the efficiency of the drainage system towards the front of the glacier would have led to a rapid thinning of this water-enhanced zone of ductile shear. Evidence from north Norfolk suggests that zones of preferential pore water flow within the glacier bed are a major controlling factor on the location of the subglacial shear zone. Consequently, the bulk of the forward motion of the glacier may not be accommodated by shearing within the sediments immediately below its base, but occur at a deeper level within the deforming bed.

\section{Introduction}

The analysis and interpretation of the structural features (folds, faults, tectonic fabrics) developed within subglacially (e.g. Berthelsen, 1979; Ben and Evans, 1996; Boulton et al., 1996; Hart and Rose, 2001; Phillips et al., 2007; Lee and Phillips, 2008) and proglacially (e.g. Berthelsen, 1979; Hart, 1990; Boulton et al., 1999; Phillips et al., 2002; Benediktsson et al., 2008) deformed sediments can provide important information on the character of glacierinduced deformation events (e.g. McCarroll and Rijsdijk, 2003). The application of techniques routinely used by structural geologists has provided key insights into the often complex polyphase deformation histories recorded by glacigenic sequences (e.g. van der Wateren, 1986; van Gijssel, 1987; van der Wateren et al., 2000; Phillips et al., 2002) leading to a greater understanding of the stresses responsible for their development (e.g. Berthelsen, 1979, Pedersen, 1993). Deformation typically involves folding and thrusting, comparable to structures found in foreland fold-and-thrust belts developed in response to crustal shortening and mountain building in areas of plate tectonic convergence. This has invariably led to the application of a thin-skinned thrust tectonic model to deformed glacigenic sequences (e.g. Croot, 1987; van Gijssel, 1987; Pedersen, 1987; Aber et al., 1989; Bakker, 2004; Andersen et al., 2005). Research on glacitectonic structures is also providing information on, and allows the elucidation of, the nature of ice-marginal sedimentation and dynamics during glacial cycles (e.g. van der Wateren, 1986, 1995; Croot, 1988; Aber et al., 1989; Ben and Evans, 1993; Harris et al., 1997; Phillips et al., 2002; Hiemstra et al., 2005).

The role played by water in controlling the style and apparent intensity of subglacial and, to a lesser extent, proglacial deformation is also increasingly being recognised (Boulton et al., 1974; van Gijssel, 1987; Boulton and Caban, 1995; Boulton et al., 2001; Baroni and Fasano, 2006; Lee and Phillips, 2008). The introduction of water into the deforming sequence 
can lead to the development of structures typically equated with intense ductile shearing (e.g. sheath folds, ductile shears) even at very low strains (van der Wateren et al., 2000; Phillips and Merritt, 2008; Lee and Phillips, 2008), aid in thrust propagation/displacement (van Gijssel, 1987; Andersen et al., 2005), and with increasing pore water pressure, the variable liquefaction and disruption of the sediment pile (Phillips et al., 2002; Phillips et al., 2007) or even catastrophic failure and water-escape (van der Meer et al., 1999; Rijsdijk et al., 1999).

Structures formed during subglacial deformation have also been used in support of the 'deforming bed' model (Boulton, 1986; Boulton and Hindmarsh, 1987; Hart and Boulton, 1991b; Hart and Roberts, 1994; Roberts and Hart, 2000, 2005). Several studies have suggested that deformation within the bed of a glacier was a major controlling factor on the dynamics of major Pleistocene ice sheets in both North America and northern Europe (Boulton and Jones, 1979; Licciardi et al., 1998; Piotrowski et al., 2001). Such deformable beds are also thought to exist beneath several contemporary ice masses, including the West Antarctic Ice Sheet (Alley et al., 1987; Evans et al., 2006). Temporal and spatial changes in the nature of subglacial deformation may control glacier movement (Alley, 1993), leading to the development of a 'stick-slip' model for basal ice flow (Fischer and Clarke, 1997; Hoeoke et al., 1997; Fischer et al., 1999). Evidence in the geological record for such a pattern of ice flow, suggests that the subglacial bed is in reality a 'mosaic' composed of zones of 'stable' and 'deforming' beds that change configuration in time and space (Piotrowski and Kraus, 1997; Piotrowski et al., 2004; Evans et al., 2006; Lee and Phillips, 2008).

This paper contributes to the study of glacier induced deformation by examining the structural evolution of highly contorted early Mid-Pleistocene pre-glacial and glacial sediments exposed along the north Norfolk coast in eastern England (Fig. 1). In this area, sediments exhibit a highly heterogeneous and often deformed appearance and have been referred to by Banham $(1968,1975,1988)$ as the 'Contorted Drift'. The variation in intensity and style of deformation recorded by these sediments is consistent with a progression from thrust-related proglacial deformation to a more complex pattern of subglacial ductile folding, thrusting and ductile shearing. The formation of the gravitational basins into which a thick glacial outwash sequence were being deposited prior to deformation, the postulated 'sag basins' of Banham (1975, 1988), Hart (1987) and Ehlers et al. (1991), has been critically reexamined. A generalised model of proglacial to subglacial deformation and the role played by pore water content on the proglacial thrust propagation and subglacial shear zone development are presented. 


\section{Location of study site and geological context}

The focus of this study is the coastal cliff sections (c. $1.5 \mathrm{~km}$ in length) between West Runton [National Grid Reference (NGR): TG 181 432] and Sheringham [NGR: TG 165 433] on the north Norfolk coast of eastern England (Fig.1). The topography of north Norfolk is dominated by a west-east trending push moraine/outwash complex called the Cromer Ridge that intersects the coastline at Trimingham (Hart, 1990). From Trimingham, westwards around the coast for approximately $14 \mathrm{~km}$ to Sheringham, the cliffs range in height from 40 to $60 \mathrm{~m} \mathrm{OD}$ and display a variably deformed sequence of Lower to Mid-Pleistocene pre-glacial and glacial sediments resting unconformably upon chalk bedrock (Banham, 1968; Hart and Boulton, 1991a; Lunkka, 1994; Rose et al., 2001; Lee et al., 2004a; Hamblin et al., 2005). Pre-glacial fluvial and shallow marine deposits correspond to the Cromer Forest-bed Formation and Wroxham Crag Formation, respectively (West, 1980; Briant et al., 1999; Allen and Keen, 2000; Rose et al., 2001; Pawley et al., 2004; Lee et al., 2006). The overlying glacial sequence consists of a number of tills and associated outwash sediments widely considered to have been deposited contemporaneously by coexisting British (Lowestoft Formation till) and Scandinavian (North Sea Drift/Cromer Tills) ice sheets during the early Mid-Pleistocene Anglian Glaciation (Marine Isotope Stage (MIS) 12) (Mitchell et al., 1973; Perrin et al., 1979; Bowen et al., 1986; Ehlers and Gibbard, 1991; Hart and Boulton, 1991a; Lunkka, 1994; Bowen, 1999; Fish and Whiteman, 2001).

More recently, a new glacial stratigraphy for the region has been proposed based upon detailed geological mapping, lithological analyses, and the examination of available sections and borehole information (Lee et al., 2004a). This new stratigraphy breaks down the glacigenic sequence into four distinctive and mappable formations, namely the Happisburgh, Lowestoft, Sheringham Cliffs and Brition's Lane formations (Lee et al., 2004a; Hamblin et al., 2005). Of critical significance is the identification that the middle (of three) North Sea Drift tills, the Second Cromer Till (Banham, 1968) or Walcott Till Member (Lee et al., 2004a), forms part of a mappable continuum with till of the Lowestoft Formation (s.s. Lowestoft Till) and, therefore, forms a regionally extensive chronostratigraphic (Anglian) marker horizon that can be traced across much of eastern and central Britain (Hamblin et al., 2000, 2005). Two other fundamental new ideas have evolved from this stratigraphic work. Firstly, detailed provenancing work undertaken on the North Sea Drift/Cromer Tills has demonstrated that they are not Scandinavian as previously considered, but derived from a British-based ice sheet (Lee et al., 2002, 2004a). Secondly, that some of the glacial deposits previously assigned to MIS 12 may correspond to earlier and/or later Middle Pleistocene 
glaciations (Hamblin et al., 2000, 2005; Lee et al., 2004b; Clark et al., 2004). This model is not supported by all lines of evidence, most notably molluscan/small mammal biostratigraphy (Preece and Parfitt, 2000) and luminescence dating (Pawley et al., 2008), and there remains an apparent conflict between multiple lines of stratigraphic evidence.

At West Runton itself, Lower and Mid-Pleistocene deposits rest upon Upper Cretaceous chalk bedrock. The pre-glacial part of this sequence consist of organic freshwater muds (Cromer Forest-bed Formation) and shallow marine sands and gravels (Wroxham Crag Formation) (West, 1980). The overlying glacigenic sediments are highly deformed (the 'Contorted Drift' of Banham, 1975, 1988) and, therefore, establishing a local stratigraphy on which to base any structural interpretation has proved difficult (see Banham, 1975, 1988; Hart, 1987; Hart et al., 1990; Hart and Boulton, 1991b; Hart and Roberts, 1994; Roberts and Hart, 2000, 2005). Although locally disrupted by thrusting and folding, elements of the glacial succession can be recognised (Table 1), and the regional stratigraphy of Lee et al. (2004a) and Hamblin et al. (2005) has proved to be the most robust when attempting to unravel the complex deformation history recorded by the glacial deposits exposed at West Runton (see below). The majority of the previous studies have agreed that the deformational overprint on the West Runton succession was subglacial in origin (Hart, 1987; Hart and Boulton, 1991b; Hart and Roberts, 1994), and has been used in support of the deforming bed model of glacier movement (Roberts and Hart, 2005). This interpretation is in marked contrast to that of Eyles et al. (1989), who considered the entire sequence as having been deposited in a glaciomarine environment as a sequence of subaqueous gravity flows.

\section{Methodology}

The depositional setting and subsequent deformation history of the glacial and pre-glacial sediments exposed between West Runton and Sheringham have been investigated using a range of macro-scale techniques. The section was described on the basis of its macro-scale features with particular emphasis placed on recording the type of bedding, sediment type, bed geometry and structure (both sedimentary and glacitectonic). The orientation of folds, foliations, faults, and lineations, as well as bedding present within the lower 1 to $2 \mathrm{~m}$ of the cliff face were recorded from a number of points along the length of the section. The sense of asymmetry of various fold phases and movement on the faults, and inter-relationships between the various generations of structures were established. Successive generations of folds (F1, F2 ....Fn), fabrics (S1, S2 ....Sn) and lineations (L1, L2 ....Ln) are distinguished by the nomenclature normally used in structural geological studies (S1 earliest fabric to Sn 
latest). However, this nomenclature does not necessarily imply that these structures were developed in response to separate deformation events (D1, D2....Dn). A sequence of overlapping photographs were taken of the cliffs enabling the analysis of the larger-scale structures developed along the entire length of the coastal section. Due to significant changes in perspective between some of the photographs, the interpretive section is divided into several overlapping segments (Figs. 2, 4 and 5). A large format (A0) supplement of this photographic interpretation and structural synthesis of the West Runton to Sheringham coastal section have been made available by the authors for download.

\section{Deformation structures and stratigraphical relationships between West Runton and Sheringham}

Published studies (e.g. Hart and Roberts, 1994; Roberts and Hart, 2005) have largely focused upon the highly complex, but relatively small-scale, structures present within the tills exposed at the base of the cliff section. The re-examination of the coastal section between West Runton and Sheringham, however, has recognised the presence of a number of large-scale deformation structures (folds, thrusts, shear zones) within this polydeformed succession, and that the style and intensity of deformation varies from east to west. This has lead to a major reinterpretation of the deformation history recorded by these sediments. For ease of description the section has been divided into three subsections or 'structural domains' (Figs. 1, 2, 4 and 5) which exhibit a similar range of deformation structures. The relationships between the main lithological units and the range of large to small-scale deformation structures present within each of these subsections are described below.

\subsection{Domain 1}

The sequence exposed at the eastern end of the coastal section (Fig. 2) is relatively undeformed and dominated by bedded, yellow to yellow brown, glaciofluvial outwash sands and gravels; the Runton Sand and Gravel Member (RSGM, Table 1). Sedimentary structures (normal grading, cross-bedding, ripple-drift lamination, trough cross-bedding) preserved within this relatively thick (up to c. $15 \mathrm{~m}$ thick) sand-dominated sequence clearly demonstrate that it is the right-way-up and has not undergone large-scale overturning during deformation. Bedding in the majority of the section is horizontal to very-gently dipping, but locally steepens (sub-vertical) immediately adjacent to a number of wedge-shaped prisms of till, forming large, open, 'dish-like' synformal structures (Fig. 2). Banham $(1975,1988)$ and Hart and Roberts (1994) interpreted these broad (50-150 m across) sand-filled features as having 
formed in response to loading, their so-called 'sag basins' (also see Roberts and Hart, 2000; Lunkka, 1994). At the eastern end of Domain 1 the RSGM rests directly upon the sands and gravels of the Wroxham Crag Formation (WCF, Table 1) (Fig. 2a). This boundary varies from an erosive sedimentary contact where the RSGM clearly cuts down through the glacial deposits into the underlying sedimentary sequence, to a glacitectonic boundary formed by a sharp planar thrust. Further west, the RSGM and WCF are separated by the variably deformed, massive to finely laminated calcareous silts and clays of the Marl Bed (MB) of the Sheringham Cliffs Formation (Table 1). The contact between the marl and underlying WCF is tectonic and formed by a subhorizontal to gently west-dipping thrust. Thrust-bound slices (up to $50 \mathrm{~cm}$ thick) of the finely stratified/foliated, brown-grey Bacton Green Till Member (BGTM) locally occur along this décollement (Figs. 2 and 3a). Bedding within the marl is locally folded and off-set by a number of small-scale thrusts which link into the décollement surface at its base. The lamination within the hanging walls of these thrusts is deformed by at least one set of small-scale normal and reverse faults, and in some instances is disrupted by a fine, vein-like network of hydrofractures filled by laminated to massive calcareous mud. In the centre and towards the western end of Domain 1, larger-scale east-verging folds and thrusts located within the MB locally propagate upwards through the sequence to deform the overlying RSGM (Fig. 2c). The east-directed thrusts have occasionally resulted in the emplacement of small (up to 1-2 $\mathrm{m}$ in length), variably folded lenses of marl into the basal sequence of the RSGM (see Fig. 2e). Locally the metre-scale folds deforming the boundary between the MB and RSGM are convolute in form and comprise narrow, steeply inclined, flame-like antiforms of marl projecting upwards into the overlying sands, separated by broad, open synforms (Fig. 3b). The axial surfaces of the folds dip towards the west, with the folds showing a slight asymmetry towards the east/east-northeast.

The main structural features present within Domain 1 are a number of large (10-15 m high, 8-10 m across), symmetrical to asymmetrical, 'saw-tooth' or 'wedge-shaped', faultbound structures composed of thrusted and folded Bacton Green Till, Marl Bed and occasionally Wroxham Crag Formation (Figs. 2 and 3a). For ease of description these internally complex features are informally referred to as 'till-prisms'. The overall size and complexity of these structures increases towards the west where they are associated with a greater intensity of deformation within the RSGM. The layering/bedding present within the thrust-bound slices of BGTM and MB steepens upwards, becoming sub-vertical within the upper parts of the 'till-prism'. Tight to isoclinal, recumbent to inclined folds which deform the stratification/layering within the till, are locally truncated by the thrusts which form the 
contacts with the adjacent slabs of marl. The base of the 'till-prisms' are marked by either a sharp planar thrust (Fig. 3a) or wider ductile shear zone; both of which link into the décollement surface at the top of the structurally underlying WCF (see Fig. 2). The shear zone (10-30 cm thick) is marked by finely foliated sand and silty sand containing thin stringers of clay-rich till. The eastern-margins of the 'till-prisms' are typically steeply inclined and formed by either a single, listric normal fault (downthrow to east), or a number of steeply inclined $\left(60-80^{\circ}\right)$, east/east-northeast-dipping, planar normal faults (also downthrow to east). The latter also occur within the adjacent RSGM and result in localised drag folding and disruption of bedding within these sands. The western margins of the 'till-prisms' are curved, and marked by either the disturbed/tectonised erosive base of the RSGM, or an arcuate, westdipping, east/east-northeast-directed thrust which over steepens towards the tip of the 'prism'.

Bedding within RSGM immediately adjacent to the 'till-prism' occurs parallel to the variably tectonised contact, and appears to locally 'drape' over the top of these bodies. In the central part of Domain 1, bedding within the RSGM defines two open anticlines linked by a syncline (Fig. 2d). These folds are developed above two smaller (8-10 m high), closely spaced 'till-prisms'. Elsewhere, however, individual sand and gravel beds thin towards the margin of the 'till-prism' and apparently either lap onto, or are truncated against this boundary. These relationships are best seen at the eastern end of the domain, as further west the RSGM becomes increasingly deformed. This deformation, where present, is most pronounced on the western side of the 'till-prisms', where the sands and gravels are folded (east/east-northeastverging) and thrusted (east/east-northeast-directed) (Fig. 2).

\subsection{Domain 2}

Continuing further westward along the coastal section, Domain 2 (Fig. 1) is characterised by a marked increase in the intensity of deformation (Fig. 4). The eastern end of the domain is dominated by a large (c. $25 \mathrm{~m}$ high, c. $35 \mathrm{~m}$ wide) wedge-shaped structure composed of eastdipping, fault/thrust-bound slabs of MB and WCF, juxtaposed against the eastern side of a triangular shaped mass of till (Figs. 3c and 4). This feature is composed of an outer layer of BGTM overlying a core of dark grey Happisburgh Till Member (HTM) (Figs. 3c and 4). Immediately to the west, the RSGM contains a number of thrust-bound lenses of MB and BGTM. (Figs. 3d and 3e). This imbricate/thrust-stacked sequence is deformed by a largescale, recumbent to gently inclined syncline (Fig. 3e and 4), the axial surface of which dips at a low-angle towards the west. Large-scale fore-sets (Fig. 3d) are well-preserved in the RSGM on the lower limb of this syncline indicating that the sequence is the right-way up. The folded 
and thrusted sediments of the RSGM are structurally underlain by the massive to highly deformed (folded and thrusted) diamictons of the BGTM overlying the HTM, which form the lower part of the cliff (Fig. 4). The boundary between the tills and overlying sands is tectonic and locally off-set by steeply west/northwest-dipping reverse faults.

The complex, wedge-like feature at the eastern end of Domain 2 is morphologically and structurally similar to the 'till-prisms' of Domain 1, and comprises a tectonically-stacked sequence of MB, BGTM, HTM and WCF, forming a steep-sided, symmetrical to weakly asymmetrical, 'saw-toothed' body which apparently 'deflects' or 'distorts' bedding in the overlying sands and gravels. The base of this structure is flat and marked by a subhorizontal thrust (Figs. 3c and 4). This thrust forms a prominent décollement surface at the top of the structurally underlying WCF. Bedding within the sands and gravels, immediately below this thrust is transposed into a finely spaced glacitectonic foliation defining a 10 to $30 \mathrm{~cm}$ thick zone of ductile shear at the top of the WCF. No obvious kinematic indicators were recognised within this shear zone; consequently the sense of movement across this structure is uncertain.

The eastern margin of the 'till-prism' is apparently a primary sedimentary contact formed by the erosive base of the RSGM, resting upon a 3 to $4 \mathrm{~m}$ thick slab of MB. The base of the marl is marked by a 25 to $40 \mathrm{~cm}$ thick shear zone composed of highly foliated and folded sand (Fig. 3f) derived from the underlying WCF. Kinematic indicators (asymmetry of folds, sigmoidal S-C-like fabric geometries, see Passchier and Trouw, 1996) present within this high strain zone indicate a sense of shear towards the east/east-northeast. The slabs of MB and WCF which form the eastern face of this till-prism dip towards the east and terminate near the top of the cliff, forming a fault-bound, hollow with 'stepped' sides and filled by RSGM (Fig. 4). Bedding within the sand is deformed by an upright, open synform. The western margin of the 'till-prism' is formed by an arcuate, steeply to gently dipping thrust which becomes progressively shallower dipping westwards, where it passes into the tectonised zone separating the BGTM and RSGM.

\subsection{Domain 3}

Domain 3 (Fig 1) represents the remainder of the coastal section between West Runton and Sheringham (Fig. 5). In this domain, the glacigenic and pre-glacial sediments are highly deformed with deformation resulting in the modification and local overprinting of the sedimentological characteristics and stratigraphical relationships between the various units. The sequence can be divided into four main components; the grey massive to moderately foliated HTM at the base of the cliff, overlain by the highly folded and foliated BGTM, which 
grades upwards into the RSGM, and a glacitectonic mélange derived from both the BGTM and RSGM. Both the BGTM and RSGM contain thrust-bound, locally stacked lenses or rafts of WCF (Figs. 5 and 6a), MB, Sheringham Cliffs Formation clay, chalky Walcott Till Member (WTM), sand and chalk bedrock. This highly deformed sequence corresponds to the 'Laminated Diamicton' of Hart and Roberts (1994).

The thickness of the HTM and BGTM increases westwards where they dominate the exposed sequence (Fig. 5). The contact between the two tills, although irregular, is generally sharp. The HTM does, however, exhibit an increase in intensity of deformation towards this boundary where it possesses an intense domainal foliation (S1), deformed by tight to isoclinal (Fig. 6b), locally intrafolial (Fig. 6c), recumbent to gently inclined folds (F1/2). Eye-shaped fold interference patterns also occur within the HTM (Fig. 6d), showing that the till has accommodated several phases of folding. The $\mathrm{S} 1$ foliation is defined by pale grey, carbonaterich layers and stringers of disaggregated chalk (Figs. 6c, e and f) which have locally undergone attenuation and boudinage (Fig. 6f) (also see Hart and Roberts, 1994; Roberts and Hart, 2000, 2005). S-C and ECC (extensional crenulation cleavage, see Passchier and Trouw, 1996) fabric geometries and off-sets on small-scale faults developed within the till yield an easterly-directed sense of shear (Fig. 6f). The HTM locally contains highly distorted augen or rafts of WTM (Fig. 7a). Flame-like projections and tails extending from the WTM pass laterally into the banded S1 fabric within the HTM. This suggests that the compositional layering within the HTM may have been partially derived from the incorporation of the WTM during deformation. S1 in the HTM is co-planar to the locally intense foliation present within the BGTM and glacitectonic layering within the structurally overlying mélange. The orientation of S1 within both tills is highly variable (Fig. 8a). However, on a lower hemisphere stereographic projection of dip and dip azimuth, the data forms two distinct clusters indicating that over the entire length of the section S1 dips either at a shallow angle towards the east-northeast, or more steeply towards the northwest (Fig. 8a). As in the HTM, the foliation within the BGTM is deformed by easterly verging, small- to meso-scale, tight to isoclinal, recumbent to gently inclined folds (Figs. 7b, c and d). In some cases, these folds are disharmonic with S1 becoming progressively disrupted and diffuse towards the hinge, indicative of the till locally containing a high-pore water content during deformation. Elsewhere, the F1/2 folds are developed in the hanging walls of S1-parallel, typically easterly directed thrusts and ductile shear zones (Fig. 7d). The gently plunging F1/2 folds are noncylindrical with curvilinear fold axial traces resulting in the observed range in fold trend shown on Fig. 8b. The folds deform a locally well-developed, north/north-northeast plunging 
(Fig. 8c) stretching lineation (L1) developed upon S1 surfaces (Fig. 7e). This lineation, therefore, predates folding. A second, southwest-plunging crenulation lineation (L2) is locally developed in the hinges of the F1/2 folds (Figs. 7c and 8c). The early recumbent to gently inclined folds are themselves deformed by later upright to moderately inclined, asymmetrical, easterly verging, small to meso-scale folds (F2/3) which plunge towards the southeast (Fig. $8 b)$.

The boundary between the BGTM and the overlying RSGM is gradational and irregular in form. At the eastern end of Domain 3, the RSGM has partially retained its wellbedded character and the boundary with the underlying BGTM can be located to within 20 to $30 \mathrm{~cm}$. In this area the RSGM is highly folded and thrusted (Figs. 5a to d) recording an overall transport direction towards the east. Further to the west, bedding is increasingly disrupted and overprinted by a glacitectonic layering which is coplanar with $\mathrm{S} 1$ in the underlying BGTM. In this part of the section (Figs. $5 \mathrm{f}$ to $\mathrm{h}$ ), the BGTM is much thicker (up to $20 \mathrm{~m}$ thick) and comprises a sandy till which grades upwards, over several metres, into a highly deformed mélange facies. The mélange was apparently derived from glacitectonic mixing of the BGTM and RSGM, consequently, locating the boundary between these two units can be problematic. A similar division of the BGTM into a lower, stratified sandy till facies and upper mélange facies has been recognised by Lee and Phillips (2008) in its type section exposed $15 \mathrm{~km}$ southeast at Bacton Green. The intensity of deformation within the mélange, which included both ductile folding and later brittle thrusting (see Figs. 5g and h), is variable and appears to have been focused/partitioned into discrete zones. In these highly deformed zones the mélange contains slab-like, asymmetrical to tightly folded lenses of sand (Figs. 5 and 7f) which are wrapped by the foliation within the host sediment. The geometry of these sand lenses records an overall sense of shear towards the east. The thrusts dip at moderate to low angles towards the west and are marked by, or occur within broader zones (up to c. 1-2 m thick) of enhanced ductile shear. Elsewhere, the layering and relict bedding within the mélange are folded by small to meso-scale east-verging structures. In one part of the section, the layering and sand lenses contained within the mélange have been deflected upwards, becoming increasingly fragmented and disrupted towards the top of the cliff (Fig. 9a). At its base this zone of disruption is c. $3 \mathrm{~m}$ across and represents an inverted funnelshaped water-escape conduit (Figs. 5g and 9a).

Along the length of Domain 3, the gradational contact between the BGTM and RSGM periodically rises to form a series of large (up to $10-15 \mathrm{~m}$ across), symmetrical to asymmetrical ridge-like features (Fig. 5). The till (both BGTM and HTM) within, and 
adjacent to these ridges is more intensely folded and thrusted (for example, see Fig. 5b). Furthermore, both the BGTM and mélange in the vicinity of these features contain a number of stacked, fault-bound slices of WCF, MB and RSGM (Fig. 5). The largest of these thrust slices or rafts is composed of well-bedded WCF and is over $50 \mathrm{~m}$ in length (Fig. 5f). The eastern end of this raft is deformed by a large-scale, southeast-plunging antiform (Figs. $5 \mathrm{f}$ and 6a). The shape of the ridges and associated deformation (including imbrication of the sequence) is comparable to that observed within the 'till-prisms' recognised in Domains 1 and 2.

The contact between the BGTM and RGSM, and that separating the BGTM from the underlying HTM, are folded by a number of meso-scale $(3-5 \mathrm{~m})$, convolute-like, upright to steeply inclined synforms (Fig. 9a, also see Figs. 5a c and e). These convolute folds deform the earlier developed S1 fabric and F1/2 folds within the tills. The limbs of the convolute folds are locally deformed by a set of southeast-plunging, inclined folds (F2/3) which result in the 'pinching' of the limbs of the synform and partial isolation of the fold nose (Fig. 9a). The cores of these convolute structures are composed a rounded to tear-drop shaped mass of thinly bedded to massive sand and gravel apparently derived from the RSGM and/or WCF. Folded, isolated slabs, lenses and augen (up to 1-2 m across) of sand derived from the WCF and RSGM occur within both the HTM and BGTM (Figs. 9c and d, also see Figs 5a to d). The asymmetry of the folds and overall shape of these sand bodies indicates a sense of shear towards the east.

At the western end of Domain 3, the boundary between the HTM and RGTM is marked by a thin ( $\leq 2 \mathrm{~m}$ thick), but laterally extensive thrust-bound raft of WCF overlying chalk (Fig. 5h). The raft preserves intact the sharp, erosive contact between these well-bedded sands and gravels, and the underlying chalk bedrock (Fig. 9e). In contrast, the chalk (10 to 40 $\mathrm{cm}$ thick) is massive and putty-like in texture, and cut by narrow (1-3 cm wide) shear zones composed of highly deformed HTM (see Fig. 9e). The HTM immediately below the raft contains highly deformed stringers and lenses of chalk, defining a variably developed foliation parallel to the base of this bedrock slab. This fabric wraps around small rounded clasts (up to c. $5 \mathrm{~cm}$ in diameter) of chalk ( \pm flint) included within the HTM. These clasts are enclosed within symmetrical to asymmetrical pressure shadows and/or elongate carbonaterich tails which record an overall east-directed sense of shear. Elongate slab-like to asymmetrical lenticular chalk rafts (up to $2.5 \mathrm{~m}$ in length), occur elsewhere within the HTM, also indicate an east-directed sense of shear and are variably deformed by recumbent F1 folds (Fig. 9f). 


\section{Proglacial to subglacial deformation model for West Runton}

Based upon the structural analysis outlined above, a number of broad conclusions can be made regarding the deformation history recorded by the Middle Pleistocene sequence exposed between West Runton and Sheringham:

- the West Runton-Sheringham sequence can be divided into three sections or structural 'domains' which internally share a similar deformation history;

- there is a marked increase in the intensity of deformation from east to west along the length of the section (Domain 1 = least deformed, Domain $3=$ most intense deformation);

- this increase in intensity is accompanied by a change from simple thrusting and imbrication in the east (Domain 1), through to a more complex history, towards the west (Domain 3), involving several phases of folding, thrusting and water-escape;

- although there is a clear variation in both the style and intensity of deformation across the three domains, the asymmetry of the folds, direction of transport on the thrusts, and asymmetry of deformed sand lenses, or augen, all yield a similar east/eastnortheast directed sense of shear, consistent with ice advancing from the west/ southwest.

The major deformation structures (folds and thrusts) developed within these glacitectonically disturbed sediments are shown in Fig. 10. The simplest interpretation of these structures is in terms of a progressive proglacial to subglacial deformation model, induced by ice advancing from the west/southwest. The sequence exposed between West Runton and Sheringham consists of pre-glacial deposits or glacial sediments laid-down during earlier ice advances. The provenance of both the HTM and BGTM indicate that they were derived from ice advancing from the north (Lee et al., 2002, 2004a). The westerly derivation of the ice resulting in deformation at West Runton marks a major change in ice flow direction.

\subsection{Proglacial deformation (Domain 1)}

Structural Domain 1 records a relatively simple deformation history dominated by eastdirected thrusting and the development of the steep-sided 'till-prisms' which locally 'puncture' the relatively undeformed RSGM (Figs. 2 and 10). This thrust-dominated deformation is interpreted as having taken place in a proglacial setting in advance of the encroaching ice sheet. At the eastern end of the section, thrusting and associated ductile 
shearing occurs at, or near to the top of the WCF (Fig. 10). This thrust system appears to represent part of the main décollement surface which formed at the base of the deforming sediment pile or could represent the reactivation of a palaeo-décollement surface formed earlier during the accretion of the Happisburgh Till (Lee, 2001). The overlying RSGM shows very little evidence of deformation, apart from immediately adjacent to the 'till-prisms' (labelled TP1 to TP 4 on Fig 10) where bedding steepens rapidly, and is locally off-set by normal faults. Further west, thrusting occurred within the finely laminated MB and resulted in the localised thrust-repetition and stacking of the pre-glacial sequence (Fig. 10). The base of the RSGM, in this area, varies from a sharp erosive contact cutting down into the underlying $\mathrm{MB}$, through to a glacitectonic contact, marked by either a thrust or deformed by narrow, tight antiforms and open synforms (Figs. 2 and 3b). These convolute-style folds indicate that the marl locally possessed a relatively high pore water content leading to soft-sediment deformation rather than thrusting. As previously stated, deformation within the RSGM is focused adjacent to the till-prisms, but further east, west-dipping thrusts ramp upwards from the basal décollement at the top of the underlying pre-glacial sediments to deform these wellbedded sand and gravels (see Figs. 2 and 10). This westerly increase in the intensity of deformation probably reflects an increase in the degree of shortening within the hanging wall of the basal décollement nearer to the ice margin.

The main structures developed in Domain 1, the 'till-prisms' (Figs. 2 and 10), are composed of highly deformed (folded and thrusted) BGTM and thrust-bound slices of MB and WCF. Consequently, these wedge-shaped features are interpreted as glacitectonic in origin. They are thought to have formed in response to deformation occurring near to the tips of the propagating thrusts as they ramped upwards through the sedimentary sequence in advance of the approaching ice sheet (see Fig. 11). Initial deformation led to folding, followed by thrusting and stacking of detached slices of the BGTM and, in some instances, the underlying pre-glacial sediments. The size and complexity of the 'till-prisms', in general, increases towards the west, i.e. in an up-ice direction (Fig. 11). The steep margins of these features (see Figs. 2, 3a and 10) are thought to preserve the original geometry of the 'tillprisms'. Consequently, their upward growth would have resulted in the observed folding and normal faulting of the adjacent RSGM (Fig. 11) as these unconsolidated sediments collapsed off of the sides of these thrust-related structures. In between the 'prisms', bedding within the RSGM was deformed into broad, open, dish-like synclines.

The 3D geometry of the thrust-related 'till-prisms' is uncertain due to the 2D nature of the coastal section. However, during the early stages of deformation and propagation of the 
thrusts into the foreland, the tip of the main décollement surface is likely to have been composed of several short thrust-segments, rather than a single laterally extensive growth tip. This would have resulted in the growth of several short, arcuate 'till-prisms' associated with each thrust segment. As deformation continued the individual thrust-segments would have begun to coalesce, leading to the development of a single elongate, sinuous, ridge-like thrustrelated moraine.

\section{2. 'Ice-marginal' deformation (Domain 2)}

Structural Domain 2 is characterised by thrusting, folding and large scale imbrication of the sequence, as well as the more pervasive deformation of the RSGM (Figs. 4 and 10). The marked increase in the intensity and complexity of thrusting and folding in this part of the section (Figs. 4, 3e and 10), is consistent with deformation having occurred in an ice-marginal setting. The eastern end of the ice-marginal zone is marked by a large, internally complex 'till-prism' (TP5 on Fig. 10) with the subhorizontal thrust at its base (Fig. 3c) representing an up-ice extension of the basal décollement beneath the proglacially deformed RSGM (Fig. 10). The E-dipping, thrust-bound slabs of MB and WCF, juxtaposed against the eastern (down-ice side) of this large wedge-shaped structure (Figs. 3c, 4 and 10) appear to have slipped down (gravity driven) this steep face. The resultant hollow formed above these displaced blocks was filled with RSGM. The presence of a large wedge-shaped till body within the path of the advancing ice sheet would have impeded forward motion of the ice. The temporary stalling of the ice is likely to have resulted in the observed thrusting and large-scale folding of the RSGM, MB and BGTM (Figs. 3e and 4) as these sediments were stacked against the western. up-ice, side of the 'till-prism' to form a large, internally complex push moraine (Fig. 10). Eventually the stacking of detached slabs of glacial and pre-glacial sediment against this moraine would have allowed the ice sheet to overcome the obstruction and resume its easterly directed advance.

The accretion of a large, relatively impermeable wedge of till within the moraine is likely to have locally affected the pattern of subglacial drainage beneath the ice sheet (Figs. 11 and 12). It may have effectively blocked the main exit for subglacial meltwater, leading to an increase in pore water pressure and/or content beneath the ice sheet. The subglacial drainage pattern would have then been forced to change with meltwater having to flow around the margins of, or even beneath the push moraine (Fig. 12). The laterally extensive WCF, which lies beneath the deformed glacigenic sequence (Fig. 10), could have provided a pathway for subglacial meltwater to escape beneath the till-rich moraine, feeding pressurised 
pore water into either: (a) the décollement horizon at the base of the proglacially deforming sequence; or (b) into the sediments immediately beneath this structure. This would have led to the lowering basal-friction, leading to an increase in thrust-gliding, changing the geometry of the thrusts and increasing the length of the detached thrust sheets (see van Gijssel, 1987; Nieuwland et al., 2000). The locally developed convolute folds and hydrofracturing within the MB provide evidence for the introduction of pressurised pore water into the basal décollement at some point during deformation. The effects of soft-sediment deformation and waterenhanced thrusting would have decreased away from the ice margin as the meltwater escaped through the permeable sands and gravels of the WCF and RSGM.

\subsection{Subglacial deformation (Domain 3)}

Structural Domain 3 represents the most pervasively deformed part of the sequence (Figs. 5 and 10). The intensity of this deformation increases towards the west and is accompanied by a marked increase in the thickness of the BGTM (see Fig. 10). This thick till can be divided into a lower, highly foliated facies, structurally overlain by a pervasively deformed glacitectonic mélange. The complex association of folding, thrusting, mélange generation and water-escape recorded by the HTM, BGTM and RSGM is interpreted as having occurred in response to progressive subglacial deformation (cf. Banham, 1975, 1988; Hart and Boulton, 1991b; Hart and Roberts, 1994; Roberts and Hart, 2000, 2005).

The deformation histories recorded by the HTM and overlying BGTM are clearly polyphase and included several phases of folding and fabric development. The earliest deformation events recorded by these tills would have accompanied their deposition. However, recognising these syndepositional deformation events, $(\mathrm{D} 1=\mathrm{HTM}, \mathrm{D} 2=\mathrm{BGTM})$, has been problematic due to the pervasive nature of the later (D3) subglacial deformation event. The orientations of the F1/2 folds (Figs. $6 \mathrm{~b}$ to $\mathrm{d}$ ) and $\mathrm{S} 1$ fabrics within the tills are highly variable (Figs. 8a and b). The asymmetry of these folds (where it can be established), sense of movement on the associated thrusts (Fig 7d) and sense of shear recorded by smallscale kinematic indicators (e.g. shear bands, minor faults and ECC fabrics; Fig. 6f) within the tills are in general consistent with the east-directed deformation imposed during D3. This suggests that earlier developed D1/D2 structures within the tills have either been overprinted or strongly modified during the later event. The curvilinear nature of the F1/2 fold axial traces, the presence of disharmonic folding and the locally diffuse nature of the S1 fabric are consistent with the BGTM possessing a relatively high pore water content at the time of deformation. This points to a very short period of time separating the deposition of the BGTM 
during D2 (ice advance from the north) and its subsequent 'reworking' or 'remobilisation' during D3 (ice advance from the west/southwest), or recharge at some point between D2 and D3.

Published macro-fabric orientations from West Runton record a pronounced northeast to southwest orientation of clast axes (Roberts and Hart, 2000) indicative of clast alignment associated with a uni-axial stress field that is characteristic of high strains within subglacial deforming beds (Hart, 1994; Benn, 1994). In detail the clustered macrofabrics are complex with clast long axes plunging either to the southwest or northeast (see fig. 19 Roberts and Hart, 2000). The development of this clast macrofabric may have accompanied the formation of the northeast/north-northeast-plunging L1 stretching lineation developed upon S1 surfaces (Figs. 7e, 8c). If correct this would suggest an ice movement direction from the northeast, consistent with macrofabric and flute evidence obtained from other sites (Happisburgh, Trimingham) in north Norfolk (Lunkka, 1988, 1994). However, shear planes from some sites at Trimingham and Happisburgh also show evidence of ice advance from the north and northwest (Hart, 1987; Lee, 2001). Roberts and Hart (2000) interpreted the West Runton macrofabric data as recording an ice movement direction from the northwest, with clast fabrics defining a girdle distribution transverse to ice flow. It is possible that the macrofabrics were imposed during the deposition of the HTM and BGTM. However, the complexity of clast long axis orientation suggests that they may have been modified during D3.

As D3 progressed, the early structures (F1/2 folds and S1 fabrics) were folded by moderately to steeply inclined, small- to meso-scale easterly verging folds (F2/3). A number of these folds are convolute in form (Fig. 9b) and result in the infolding of RSGM into the structurally underlying BGTM and HTM. These meso-scale soft-sediment deformation structures provide further evidence that the BGTM and RSGM were highly mobile during D3 consistent with a high pore water contents and/or pressures during subglacial deformation. East-directed thrusting during D3 largely post-dated folding and resulted in the stacking of thrust-bound slabs (or rafts) of HTM, BGTM, WCF and RSGM (Fig. 10). This modified the original stratigraphic relationships between these units and led to the tectonic thickening of the sediment pile beneath the ice sheet. The thrusts probably formed during earlier proglacial to ice-marginal deformation and were periodically reactivated in response to shear imposed by the overriding ice. The contrast between the highly ductile soft-sediment deformation and more brittle thrusting indicates that pore water contents/pressures fluctuated during D3, either in response to seasonal fluctuations in meltwater production and/or changes in the efficiency in the drainage at the front of the ice sheet. 
The symmetrical to asymmetrical ridge-like features in the subglacially deformed part of the section (labelled TP6 to 12 on Fig. 10) are morphologically and structurally similar to the thrust-related moraines ('till-prisms') developed in response to proglacial deformation (see above). However, the over-steepened, wedge-shaped morphology of these features is less pronounced within Domain 3, consistent with their modification during subglacial D3 deformation. The presence of these relict proglacial features within the bed of the overriding ice sheet apparently acted as a focus for continued (subglacial) thrusting and shearing. The resultant brittle thrusts and ductile shear zones propagated upwards into deform the mélange facies of the BGTM (see section adjacent to TP12, Fig. 10). On the immediate up-ice side of one of these overridden moraines (TP12, Fig 10), the mélange is cut by a large-scale waterescape conduit (Figs. $5 \mathrm{~g}$ and $9 \mathrm{a}$ ). The base of this water-escape feature terminates or roots into the contact between the BGTM and underlying HTM, suggesting that pressurised pore water was flowing along this lithological boundary. The presence of water-escape features provides further evidence that the BGTM was saturated with water at the time of deformation and that pore water pressures locally exceeded the cohesive shear strength of these sediments. The location of this conduit in the immediate up-ice side of one of these remnant 'till-prisms' suggests that there may be a link between the two structures. Glacier induced stress would have built up on the up-ice side of these relict proglacial features, not only leading to thrusting, but potentially an increase in pore water pressure. This localised pressure increase may have controlled the location of the observed, potentially catastrophic, water-escape.

\section{Formation of a subglacial shear zone in response to subglacial deformation}

The intensity of subglacial deformation recorded by the BGTM and RSGM increases towards the western end of the West Runton to Sheringham section (Figs. 10 and 12). This is accompanied by the marked thickening of the BGTM and disruption and variable overprinting of bedding in the RSGM. The boundary between the two units becomes increasingly 'blurred' with the gradation between the BGTM and RSGM leading to the conclusion that the mélange formed as a result of the glacitectonic mixing of the two units during D3. At Bacton Green, 15 $\mathrm{km}$ to the southeast, the mélange facies of the BGTM has been interpreted by Lee and Phillips (2008) as having developed in response to the development of a subglacial shear zone. At West Runton, the subglacial shear zone (D3 in age) is represented by the mélange facies (c. 20-25 m thick) of the BGTM which thickens westwards (i.e. in an up-ice direction) where it is composed of a complex, anastomosing network of shallowly to moderately west-dipping thrusts and broader ductile shear zones wrapping around apparently lower strain areas (Fig. 
12; also see Fig. 15). In these low strain domains, the glacitectonic layering and locally preserved bedding are deformed by east-verging asymmetrical shear folds.

Two contrasting models have been published to explain the evolution and deformation of subglacial tills. The first suggests that subglacial deformation is pervasive and that all subglacial till facies (melt-out tills, lodgement tills...etc) ultimately undergo shearing and should, therefore, be classified as deforming bed tills (van der Meer et al., 2003; Menzies et al., 2006). The second model argues that a spatial and temporal 'mosaic' comprising actively deforming and stable (non-deforming) zones develop within the subglacial deforming bed (Piotrowski and Kraus, 1997) in response to either the degree of water-induced decoupling at the ice-bed-interface (IBI) (Hoffman and Piotrowski, 2001), or the ability of the subglacial bed to drain inter-granular pore water (Piotrowski et al., 2004). Evans et al. (2006) and Lee and Phillips (2008) argue that the deformation of the glacier bed comprises elements of both models with the pattern of deformation changing temporally and spatially.

As at Bacton Green, macroscopic structural evidence from the West Runton to Sheringham section suggests that subglacial deformation of the BGTM and RSGM involved a shifting pattern of relatively 'high' and 'low' strain zones. During the earlier stages of D3 shear stress imposed by the overriding glacier ice was being transmitted throughout the entire subglacial bed resulting in the formation and contemporaneous deformation of the mélange, with ductile folding also effecting the lower parts of the BGTM and upper part of the HTM (Fig. 12); as predicted by Hart and Boulton (1991b) and van der Wateren et al. (2000). Subsequently, deformation within the mélange was preferentially partitioned into discreet zones of enhanced ductile shear. This partitioning is likely to have been controlled by the variation in pore water content and the rate of thickening of the mélange, with deformation being focused into the relatively weaker, 'water-rich' (dilated) parts of the sequence (cf. Evans et al., 2006; Lee and Phillips, 2008). The highly deformed and disrupted nature of the mélange suggests that it probably accommodated the bulk of the shear being transmitted into the deforming bed and, therefore, the majority of the displacement achieved by the overriding glacier ice. During the later stages of D3, however, ductile deformation was superseded by brittle thrusting. This change in deformation mechanism probably reflects a fall in the pore water content and locking up of the subglacial shear zone. Dewatering during the later stages of D3 was probably instigated by the overburden pressure exerted by the overriding ice and assisted by the tectonic thickening and accretion of the deforming bed (Lee and Phillips, 2008). 
The thickening of the BGTM, in particular, the highly deformed mélange facies, towards the west (Fig. 10) indicates that the subglacial shear zone also widened in this up-ice direction. The initial formation of the shear zone, followed by the disruption and mixing of the RSGM with upper part of the BGTM, may have been aided by the migration of meltwater through the sediment pile. The enhanced drainage near to the front of the glacier would negate the build up of meltwater, limiting the potential for water-enhanced ductile shear in this more ice-marginal setting (see Fig. 12). Instead deformation was dominated by heterogeneous folding and thrusting. Further up-ice, however, subglacial drainage would become increasingly restricted, with the overlying glacier forming an impermeable 'cap' forcing water to travel laterally through the deforming sediment pile or at the ice-bed-interface. The overconsolidated nature of the HTM near the base of the sequence would have concentrated this fluid flow within the BGTM and overlying RSGM. As deformation progressed, the introduction of additional subglacial meltwater from up-ice would have led to the increasing dilation and weakening of the BGTM and RSGM. This would have resulted in the expansion, both vertically (upwards) and laterally (sideways) of the shear zone, progressively incorporating more of the adjacent sediments into the glacitectonic mélange. The developing shear zone would have provided an ideal pathway for fluid migration, further feeding this water lubricated system. During the later stages of D3, the water content of the sediment decreased and fluid enhanced shearing was arrested, leading to the 'locking up' and 'collapse' of the subglacial shear zone. This 'locking' of the system is recorded by renewed brittle thrusting during the later stages of D3. Importantly, field evidence suggests that rather than developing immediately below the overlying glacier (as predicted by the deforming bed model Boulton and Hindmarsh, 1987; Hart and Boulton, 1991b), the shear zone formed along a major lithological boundary deep within the deforming sediment pile (Fig. 12). The lithological contrasts (clayey till beneath, sand above) would have led to the focusing of fluid flow along this boundary, indication that water content is a major contributing factor in the sighting of the subglacial shear zone.

The periodic accretion of impermeable prisms of till to the push moraine at the front of the advancing glacier (Fig. 12; see section 3.2) would have locally retarded/blocked icemarginal drainage, leading to a further build-up of pore water contents/pressures up-ice. In theory this process could have led to the rapid down-ice expansion of the subglacial shear zone. As this 'till-prism' was overridden, meltwater would once again be able to drain from the front of the glacier and the zone of water enhanced shear would have retreated back upice. Seasonal or longer term fluctuations in pore water pressure and/or content in the 
subglacial environment, coupled with the periodic accretion of till-rich slabs into the push moraine could have lead to several periods of 'expansion' and 'contraction' of the subglacial shear zone. The result was that the sediments within the deforming bed were imprinted with a complex sequence of cross-cutting, polyphase deformation structures during D3.

\section{Syntectonic proglacial deposition of the glacial outwash sands of the Runton Sand and}

\section{Gravel Member}

Banham (1975, 1988), Hart (1987) and Roberts and Hart (2000) have regarded the large dishlike basins at West Runton to have formed through gravity loading of the underlying saturated tills (BGTM and HTM) by the braided outwash sediments (RSGM). They concluded that the sub-vertical aspect of the layering with the wedge-like till bodies separating these so-called 'sag basins' occurred in response to diapiric loading during basin formation. One major problem with this model is that it requires the complete removal of a thick sequence (up to c. $20-25 \mathrm{~m}$ ) of till from beneath these basins, without disturbing the bedding within the central part of the basin (see Figs 2 and 10). No features supporting the 'expansion' of the sediment pile adjacent to the basins by material displaced from beneath these depositional centres, or evidence of large-scale 'mushroom-like' folding (Banham, 1975, 1988), or small-scale diapiric movement of till, have been recognised in the West Runton to Sheringham section.

The simplest interpretation of the RSGM is that it represents a glacitectonically disturbed proglacial outwash succession. This sand and gravel sequence cut down into, and removed parts of, the older, glacial and pre-glacial sedimentary succession. The pattern of erosion may have been controlled either by: (a) a palaeotopographic surface left after the retreat of the ice which laid down the BGTM; or (b) the development of a peripheral forebulge in front of an advancing glacier in response to loading caused by the weight of ice (similar to features developed elsewhere in the geological record in front of large-scale thrust sheets). The RSGM outwash is thought to have been laid down in front of the westerly advancing ice responsible for the bulk of the deformation at West Runton to Sheringham. As the glacier encroached into, and progressively overrode this succession it resulted in the observed proglacial to subglacial deformation continuum. The overall size and geometry of the 'till-prisms' (see Fig. 11), formed in response to proglacial thrusting, suggests that they are likely to have formed positive topographic features within outwash sandur, controlling sediment distribution and the formation of rounded to elongate sub-basins between the moraines (Figs. 11 and 13). The growth of these moraines during sedimentation would have led to deformation (e.g. normal faulting) of the sediments at the margins of the sub-basins, 
whilst deposition continuing in the centre of the basin (Fig. 11). As the glacier encroached further to the east, the RSGM in the centre of the sub-basins would have progressively deformed and been eventually overridden.

\section{Discussion}

\subsection{Implications for the glacial history of north Norfolk}

The deformation history erected for the glacigenic sequence at West Runton contributes to the broader understanding of the glacial history of north Norfolk during the Middle Pleistocene. The highest stratigraphic unit within this deformed succession is the Bacton Green Till Member of the Sheringham Cliffs Formation (Table 1). This demonstrates that this till and all lower units within the sequence, namely the Happisburgh Till, Walcott Till and Marl Bed (Table 1), had all been deposited prior to deformation. The deposition of the BGTM occurred in association with an ice advance from the north/northwest (Banham, 1968, 1988; Lee et al., 2004a). However, kinematic indicators from West Runton (this study) and other sites within the region such as Bacton Green (Lee and Phillips, 2008), indicate that the till and underlying sediment pile was subsequently overridden and deformed during an ice advance from the west/southwest. Regionally, this later ice advance appears to be associated with the deposition of the chalk-rich Weybourne Town Till Member or 'Marly Drift' across much of north Norfolk (West and Donner, 1956; Perrin et al., 1979; Straw, 1983; Ehlers et al., 1991; Fish and Whiteman, 2001; Pawley et al., 2004; Pawley, 2006) (Fig. 14).

The predominantly ductile style of deformation and mixing suggests that pore water content and/or pressure, especially within the BGTM, was high at the onset/during this later deformation event. This implies firstly, that either a short time interval existed between the deposition of the BGTM and its subsequent remobilisation, or secondly, that pore water content within the BGTM was recharged between deposition and deformation and that a long time period existed between the two. Whilst the second option cannot be discounted as icemarginal areas of temperate ice sheets are often water-rich landsystems (Evans and Twigg, 2002), the wider regional stratigraphy would appear to preclude the possibility of two Middle Pleistocene ice advances from the west/southwest during different glaciations. Critical evidence is the preservation of MIS 11 Hoxnian (Holsteinian) sites situated on Lowestoft Formation till at Barnham (Ashton et al., 1994), Elvedon (Ashton et al., 2000) and West Stow (Preece et al., 2007) in Central East Anglia that would have been highly tectonised or even destroyed has they been overridden by a later ice advance. The simplest model is that the Lowestoft Formation till (WTM and Lowestoft Till Member of southern and central East 
Anglia), BGTM and Weybourne Town Till Member were deposited during the same (MIS 12) glacial episode but during different ice marginal oscillations (Fig. 14).

\subsection{Generalised model of progressive proglacial to subglacial deformation}

The proposed model of proglacial to subglacial deformation erected for the polydeformed sequence exposed between West Runton and Sheringham has implications for the study of similar sequences which have undergone glacitectonic disturbance.

The intensity and extent of proglacial deformation will be dependant upon not only the size of the glacier/ice sheet, but also the nature of the sequence within the foreland, to the front of the advancing glacitectonic thrust-complex. At West Runton proglacial deformation appears to have occurred well in advance of the ice margin and was dominated by thrusting. The length of exposed section which has undergone proglacial thrusting (Domain 1) suggests that in some instances deformation may extend over 0.5 to $1 \mathrm{~km}$ in front of the advancing glacier. Initially deformation within the foreland will be focused around the ends of the propagating thrusts as they ramp upwards through the proglacial sequence (Fig. 15). These individual thrusts curve downward linking into a prominent décollement surface, or basal thrust, located at a deeper level within the sediment pile. At West Runton this basal décollement developed along a laterally extensive, major lithostratigraphic boundary which separates the older pre-glacial succession and underlying chalk bedrock, from the younger glacial sediments. The presence of laterally extensive planes of weakness (e.g. a lithological boundary, the sediment-bedrock interface) within the proglacial succession will control the depth of this décollement and the thickness of the deforming sequence. The overall complexity and intensity of proglacial deformation within the hanging wall of this décollement increases towards the ice front. This is primarily due to a progressive increase in the amount of shortening having to be accommodated by the sediment pile nearer to the ice margin.

Experimental data suggests that the structural style and geometric characteristics of the proglacial thrust-complex developing above the basal décollement is strongly controlled by the frictional properties of the sequence beneath this surface (Davis et al., 1984; Nieuwland et al., 2000). The presence of low-frictional, water-rich sediments (e.g. Marl Bed) within the sediment pile may assist thrust propagation into the foreland (Fig. 15) (cf. van Gijssel, 1987; Andersen et al., 2005). At West Runton, soft-sediment deformation of the MB indicates that it possessed a high pore water content at the time of deformation, leading to thrust-sheet gliding and detachment of much longer slabs of relatively undeformed sediment; 
aiding in the preservation the proglacial sub-basins filled by the RSGM. The frictional properties of the sediments beneath the basal décollement may be changed from, for example, high-frictional sand, to a low-frictional substrate by the simple addition of meltwater; the latter resulting in the dilation and weakening of the sediment. This would have the effect of lubricating the basal thrust, focusing proglacial deformation into this water-rich zone and potentially switching off deformation within its hanging wall. A change in hydrogeological system at the ice margin from one which allowed 'open' or 'free' drainage of subglacial meltwater, to a more 'restricted' system which retards the escape of meltwater from beneath the glacier, may result in pressurised pore water being forced deeper into the sediment pile and further out into the foreland (Fig. 15). At West Runton, this change in the hydrogeological system may have occurred in response to the accretion of a large, impermeable wedges-like bodies of till into the push-moraine (see Figs. 11 and 15). Subglacial meltwater would then have been forced around, or beneath this impermeable barrier into the permeable sands and gravels of the WCF. This laterally extensive lithostratigraphic unit would have enabled meltwater to penetrate further out into the proglacial foreland, aiding deformation of the sediment pile. Seasonal fluctuations in subglacial meltwater production may, therefore, lead to a variation in the rate of thrust propagation into the foreland and an increase in proglacial deformation during the spring/summer.

Deformation at the leading edge of the main thrust, or associated out-of-sequence thrusting, can lead to the development of positive topographic features or thrust-related moraines some distance in front of the advancing ice front (Figs. 13 and 15). These features may be composed of a combination of thrusted older glacial sediments and/or detached slabs of bedrock. At West Runton these thrust-related moraines are thought to have controlled sediment dispersal and led to the formation of small sub-basins between the morainic ridges. The accretion and incorporation of these proglacial morainic features into the main push moraine forming at the margin of the advancing glacier may, depending on their size, temporarily stalled forward motion of the ice. Thrusting and large-scale folding associated with ice-marginal deformation would lead to the stacking of material excavated from further up-ice onto the stoss-side of these accreted proglacial thrust-related features (Fig. 15). This type of deformation is a characteristic feature of many ancient and recent push moraines; for example the Lamstedt Moraine (Germany) (van Gijssel, 1987), Dammer push moraine (Germany) (van der Wateren, 1987), the Cromer Ridge (eastern England) (Hart, 1990), Holmstróbreen push moraine complex (Spitsbergen) (Boulton et al., 1999), and the 1890 end 
moraine at Brúarjökull (Iceland) (Benediktsson et al., 2008). The effect would be to lower the gradient of the ice-contact margin so that the glacier can override the obstruction. As they are overridden the positive topography of the thrust-related ridges would be lowered and their ridge-like form dissected. Subsequent subglacial deformation may lead to the progressive moulding of these relict proglacial features to form streamlined features composed of folded and thrusted glacial sediment and possibly bedrock (Fig. 15). At West Runton, these overridden relict proglacial features appear to have been a focus for later subglacial thrusting.

Subglacial deformation can be highly variable in its style and intensity (e.g. Hart and Boulton, 1991b; Benn and Evans, 1996) ranging from heterogeneous folding and thrusting, through to more pervasive ductile shearing and the formation of a subglacial shear zone. These events may be superimposed upon earlier, penecontemporaneous, proglacial phase of deformation potentially leading to a complex polyphase deformation history during a single phase of ice advance (e.g. van der Wateren, 1986; van Gijssel, 1987; Phillips et al., 2002). Deformation structures developed during the proglacial deformation or even older deformation events may be reactivated leading to the reworking of earlier glacitectonic deposits. This may lead to the modification, overprinting or superposition of several phases of folds, fabrics and clast macrofabrics within an older till (e.g. BGTM). It is possible, therefore, that some of the tills in the geological record are 'polycyclic' and have undergone several (?unrelated) phases of deformation prior to dewatering and final consolidation. This 'recycling' may aid in the homogenisation of the tills and the formation of the 'tectomict' of van der Meer et al. (2003).

The intensity of subglacial deformation increases up-ice and can lead to the overprint of the original stratigraphical relationships between the units within the deforming bed. At several sites along the north Norfolk coast (e.g. West Runton, this study; Bacton Green, Lee and Phillips, 2008) this has accompanied the generation of a glacitectonic mélange and formation of a subglacial shear zone. Deformation within the shear zone is thought to accommodate most of the movement of the overriding glacier, with deformation being partitioned into an anastomosing network of relatively 'high strain' zones which progressively shift through the deforming bed (Piotrowski and Kraus, 1997; Hoffman and Piotrowski, 2001; van der Meer et al., 2003; Piotrowski et al., 2004; Evans et al., 2006; Lee and Phillips, 2008). Partitioning of deformation is likely to have been controlled by the variation in pore water content, which, in extreme cases, may lead to the decoupling of the glacier from its bed. During dewatering the shear zone begins to 'lock' and earlier ductile deformation is superseded by a more brittle mechanism, such as thrusting. Evidence from West Runton 
indicates that the thickness and complexity of the subglacial shear zone increases in an up-ice direction (see Figs. 10 and 15). The increased efficiency of drainage near the glacier margin leads to a rapid thinning, or even 'collapse', of the subglacial shear zone. The net result is a rapid deceleration in forward motion adjacent to the ice front, leading to the overall compressive nature of deformation within the ice near to the glacier margin (Fig. 15). The width of this 'deceleration zone' is dependant upon the proximity of the onset of subglacial shear zone formation to the ice front, which is in turn linked to the efficiency of the subglacial to ice marginal drainage system.

In many studies it is assumed that the subglacial shear zone develops immediately below the overriding glacier (Hart, 1994; Roberts and Hart, 2005), consistent with the deforming bed model (Boulton and Hindmarsh, 1987; Hart and Boulton, 1991b) and leading to an increase in intensity of deformation upwards through the sediment pile (Hart and Boulton, 1991b; van der Wateren et al., 2000). At West Runton, however, subglacial shear was instigated along a major lithological boundary located at a deeper level within the bed, rather than at the ice-sediment interface (see Fig. 15). The lithological contrast between relatively impermeable clay-rich till beneath (BGTM) and free-draining sand and gravel (RSGM) above, led to the concentration in the flow of meltwater along this boundary leading to the partitioning of water-enhance ductile shear along this contact. The presence of zones of preferential pore water flow within the bed of the glacier could represent a major contributing factor in the sighting of the subglacial shear zone. Consequently, the bulk of the forward motion of the glacier may not be accommodated by shearing within the sediments immediately below its base, but occur at a deeper level within the deforming bed (c.f. Truffer et al., 2000).

\section{Conclusions}

A number of conclusions can be made regarding the polyphase deformation history recorded by the pre-glacial and glacial sediments exposed in the coastal section between West Runton and Sheringham (eastern England):

- The simplest interpretation of the main glacitectonic event (D3) to have effected these sediments is in terms of a progressive proglacial to subglacial deformation model. This event was associated with the advance of a major Middle Pleistocene (Anglian) ice sheet from the west/southwest, marking a major change in ice flow direction across north Norfolk. 
- Proglacial deformation occurred well in advance of the ice margin and was dominated by thrusting, leading to the formation of steep-sided moraines composed of detached blocks of highly deformed till. These thrust-related moraines are through to have formed positive topographic features within the outwash sandur which controlled sedimentation during the deposition of the Runton Sand and Gravel Member.

- The basal thrust or décollement beneath the proglacially deforming sequence was located along a major lithostratigraphic boundary separating the older pre-glacial succession (Wroxham Crag Formation) and underlying chalk bedrock, from the younger glacial sediments.

- Accretion of the proglacial thrust-related moraines to the main push moraine formed at the margin of the advancing glacier may have temporarily stalled forward motion of the ice. Thrusting and large-scale folding associated with ice-marginal deformation led to the stacking of material excavated from further up-ice onto the stoss-side of these accreted moraines enabling the glacier to override these temporary obstructions.

- Subsequent subglacial deformation was highly variable in its style and intensity ranging from heterogeneous folding and thrusting, through to more pervasive ductile shearing and the formation of a subglacial shear zone. These events were superimposed upon earlier, penecontemporaneous, proglacial and ice marginal phases of deformation, and accompanied the remobilisation and reworking of earlier glacitectonic deposits.

- The thickness and complexity of the subglacial shear zone increases in an up-ice direction where it is characterised by a thick glacitectonic mélange. Fluctuations in pore water content and/or pressure are thought to have controlled the pattern of deformation within the shear zone with an increase in the efficiency of drainage towards the front of the glacier leading to a rapid thinning, or 'collapse', of the shear zone. This would have led to a potentially rapid deceleration in forward motion adjacent to the ice front and overall compressive flow regime within the ice near to the glacier margin. 
- Evidence from the north Norfolk coast indicates that the subglacial shear zone preferentially developed along a major lithostratigraphic boundary within the deforming sediment pile. This suggests that the bulk of glacier may not be accommodated by shearing within the sediments immediately below its base, but occur at a deeper level within the deforming bed.

\section{Acknowledgements}

This work forms part of the Quaternary Palaeoenvironments and Landscapes Project of the British Geological Survey. Andrew Finlayson, Nick Golledge, Richard Hamblin, Brian Moorlock, Julian Murton, Steven Pawley, Jim Rose, Dave Roberts, Richard Waller and Colin Whiteman are thanked for many discussions. Martyn Stoker is thanked for his comments of an earlier draft of the manuscript. John Hiemstra and Geoff Thomas are both acknowledged for their very constructive reviews of this paper. This paper is published with the permission of the Executive Director of the British Geological Survey (NERC).

\section{References}

Aber, J.S., Croot, D.G., Fenton, M.M. 1989. Glaciotectonic Landforms and Structures. Kluwer, Dordrecht.

Allen, P., Keen, D.H. 2000. Uppermost Norwich Crag and Lower part of the Cromer Forestbed Formations. In Lewis, S.G., Whiteman, C.A., Preece, R.C. (Eds). The Quaternary of Norfolk and Suffolk, Field Guide. Quaternary Research Association, London, 29-34.

Alley, R.B., Blankenship, D.D., Bentley, C.R. and Rooney, S.T. 1987. Till beneath Ice Stream B, 4. A coupled ice-till flow model. Journal of Geophysical Research 92, 8921-8929.

Andersen, L.T., Hansen, D.L., Huuse, M. 2005. Numerical modelling of thrust structures in unconsolidated sediments: implications for glaciotectonic deformation. Journal of Structural Geology 27, 587-596. 
Ashton, N.M., Bowen, D.Q., Holman, J.A., Hunt, C.O., Irving, B.G., Kemp, R.A., Lewis, S.G., McNabb, J., Parfitt, S., Sedddon, M.B. 1994. Excavations at the Lower Palaeolithic site at East Farm, Barnham, Suffolk 1989-92. Journal of the Geological Society of London 151, 599-605.

Ashton, N., Lewis, S.G., Parfitt, S.A. 2000. East Farm, Barnham, Suffolk (TL 875787). In Lewis, S.G., Whiteman, C.A., Preece, R.C. (Eds). The Quaternary of Norfolk and Suffolk, Field Guide. Quaternary Research Association, London, 165-166.

Bakker, M.A.J. 2004. The internal structure of Pleistocene push moraines: a multidisciplinary approach with emphasis on ground-penetrating radar. Unpublished $\mathrm{PhD}$ thesis, Queen Mary, University of London.

Banham, P.H. 1968. A preliminary note on the Pleistocene stratigraphy of north-east Norfolk. Proceedings of the Geologists' Association 79, 469-474.

Banham, P.H. 1975. Glacitectonic structures: a general discussion with particular reference to the contorted drift of Norfolk. In Wright, A.E., Moseley, F. (Eds). Ice Ages: Ancient and Modern. Seel House Press, Liverpool, 69-94.

Banham, P.H. 1988. Polyphase glacitectonic deformation in the Contorted Drift of Norfolk. In Croot (Ed). Glaciotectonics: Forms and Processes. Balkema, Rotterdam, 27- 32.

Baroni, C., Fasano, F. 2006. Micromorphological evidence of warm-based glacier deposition from the Picker Hills Tillite (Victoria Land, Antarctica). Quaternary Science Reviews 25, 976-992.

Benediktsson, I.O., Möller, P., Ingólfsson, Ó., van der Meer, J.J.M., Kjær, K.H., Krüger, J. 2008. Instantaneous end moraine and sediment wedge formation during the 1890 glacier surge of Brúarjökull, Iceland Quaternary Science Reviews 27, 209-234.

Benn, D.I. 1994. Fabric shape and the interpretation of sedimentary fabric data. Journal of Sedimentary Research A64, 910-915. 
Benn, D.I., Evans, D.J.A. 1993. Glacimarine deltaic deposition and ice-marginal tectonics: the 'Loch Don Sand Moraine', Isle of Mull, Scotland. Journal of Quaternary Science 8, 279-291.

Benn, D.I., Evans, D.J.A. 1996. The interpretation and classification of subglacially deformed materials. Quaternary Science Reviews 15, 23-52.

Berthelsen, A. 1979. Recumbent folds and boudinage structures formed by subglacial shear: an example of gravity tectonics. Geologie en Mijnbouw 58, 253-260.

Boulton, G.S. 1986. A paradigm shift in glaciology. Nature 322, 18.

Boulton, G.S., Jones, A.S. 1979. Stability of temperate ice caps and ice sheets resting on deformable sediment. Journal of Glaciology 24, 29-43.

Boulton, G.S. and Hindmarsh, R.C.A. 1987. Sediment deformation beneath glaciers: rheology and geological consequences. Journal of Geophysical Research 92, 9059-9082.

Boulton, G.S., Caban, P. 1995. Groundwater flow beneath ice sheets, Part II. Its impact on glacier tectonic structures and moraine formation. Quaternary Science Reviews 14, 563-587.

Boulton, G.S. Dent, D.L., Morris, E.M. 1974. Subglacial shearing and crushing, and the role of water pressures in tills from south-east Iceland. Geografiska Annaler 56A, 135-145.

Boulton, G.S., van der Meer., J.J.M., Hart, J., Beets, D., Ruegg, G.H.J., van der Wateren, F.M., Jarvis, J. 1996. Till and moraine emplacement in a deforming bed surge - an example from a marine environment. Quaternary Science Reviews 15, 961-987.

Boulton, G.S., van der Meer., J.J.M., Hart, J., Beets, D., Hart, J.K., Ruegg, G.H.J.. 1999. The sedimentary and structural evolution of a recent push moraine complex: Holmstrǿbreen, Spitsbergen. Quaternary Science Reviews 18, 339-371.

Boulton, G.S., Dobbie, K.E., Zatsepin, S. 2001. Sediment deformation beneath glaciers and its coupling to the subglacial hydraulic system. Quaternary International 86, 3-28. 
Bowen, D.Q., Rose, J., McCabe, A.M., Sutherland, D.G. 1986. Quaternary glaciations in England, Ireland, Scotland, and Wales. Quaternary Science Reviews 5, 299-340.

Bowen, D.Q (Ed) 1999. A Revised Correlation of Quaternary Deposits in the British Isles. Geological Society of London Special Report No. 23.

Briant, R.M., Rose, J., Branch, N.P., Lee, J.A. 1999. 'Pre-glacial' Quaternary sediments from Trimingham, north Norfolk, England. Bulletin of the Geological Society of Norfolk 49, 1547.

Clark, P.U., Alley, R.B. and Pollard, D. 1999. Northern Hemisphere ice-sheet influences on global climate change. Science 286, 1104-1111.

Croot, D.G. 1987. Glaciotectonics: Forma and Processes. Balkema, Rotterdam.

Davis, D., Suppe, J., Dahlen, F.A. 1984. Mechanics of fold-and-thrust belts and accretionary wedges: Cohesive Coulomb theory. Journal of Geophysical Research 89, 10087-10101.

Ehlers, J., Gibbard, P.L. 1991. Anglian glacial deposits in Britain and the adjoining offshore regions. In Ehlers, J., Gibbard, P. L., Rose, J. (Eds). Glacial Deposits of Great Britain and Ireland. Balkema, Rotterdam, 17-24.

Ehlers, J., Gibbard, P.H., Whiteman, C.A. 1991. The glacial deposits of northwest Norfolk. In Ehlers, J., Gibbard, P. L., Rose, J. (Eds). Glacial Deposits of Great Britain and Ireland. Balkema, Rotterdam, 223-232.

Evans, D.J.A., Twigg, D.R. 2002. The active temperate glacial landsystem: a model based on Breiðamerkurjökull and Fjallsjokull, Iceland. Quaternary Science Reviews 21, 2143-2177.

Evans, D.J.A., Phillips, E.R., Hiemstra, J.F., Auton, C.A. 2006. Subglacial till: Formation, sedimentary characteristics and classification. Earth Science Reviews 78, 115-176. 
Evans, J., Dowdeswell, J.A., Ó Cofaigh, C., Benham, T.J., Anderson, J.B. 2006. Extent and dynamics of the West Antarctic Ice Sheet on the outer shelf of the Pine Island Bay during the last glaciation. Marine Geology 230, 53-72.

Eyles, N., Eyles, C.H., McCabe, A.M. Sedimentation in an ice-contact subaqueous setting: the Mid-Pleistocene 'North Sea Drifts' of Norfolk, UK. Quaternary Science Reviews 8, 57-74.

Fish, P.R., Whiteman, C.A. 2001. Chalk micropalaeontology and the provenancing of Middle Pleistocene Lowestoft Formation till in eastern England. Earth Surface Processes and Landforms 26, 953-970.

Fischer, U.H., Clarke, G.K.C. 1997. Stick-slip sliding behaviour at the base of a glacier. Annals of Glaciology 24, 390-396.

Fischer, U.H., Clarke, G.K.C., Blatter, H. 1999. Evidence for temporally varying sticky spots at the base of Trapridge Glacier, Yukon Territory, Canada. Journal of Glaciology 45, 352360.

Hamblin, R.J.O, Moorlock, B.S.P., Rose, J. 2000. A New Glacial Stratigraphy for Eastern England. Quaternary Newsletter 92, 35-43.

Hamblin, R.J.O., Moorlock, B.S.P., Rose, J., Lee, J.R., Riding, J.B., Booth, S.J., Pawley, S.M. 2005. Revised Pre-Devensian glacial stratigraphy in Norfolk, England, based on mapping and till provenance. Geologie en Mijnbouw 84, 77-85.

Hart, J.K. 1987. The genesis of the north east Norfolk Drift. Unpublished PhD thesis, University of East Anglia.

Hart, J.K. 1990. Proglacial glaciotectonic deformation and the origin of the Cromer Ridge push moraine complex, North Norfolk, England. Boreas 19, 165-180.

Hart, J.K. 1994. Till fabric associated with deformable beds. Earth Surface Processes and Landforms 19, 15-32. 
Hart, J.K., Boulton, G.S. 1991a. The glacial drifts of Norfolk. In: Ehlers, J., Gibbard, P. L., Rose, J. (Eds). Glacial Deposits of Great Britain and Ireland. Balkema, Rotterdam, 233-243.

Hart, J.K., Boulton, G.S. 1991b. The interrelation of glaciotectonic and glaciodepositional processes within the glacial environment. Quaternary Science Reviews 10, 335-350.

Hart, J.K., Roberts, D.H. 1994. Criteria to distinguish between glaciotectonic and glaciomarine sedimentation: I - Deformation style and sedimentology. Sedimentary Geology 91, 191-213.

Hart, J.K, Rose, J. 2001. Approaches to the study of glacier bed deformation. Quaternary International 86, 45-58.

Hart, J.K., Hindmarsh, R.C.A., Boulton, G.S. 1990. Different styles of subglacial deformation in the context of the Anglian ice sheet. Earth Surface Processes and Landforms 15, 227-241.

Harris, C., Williams, G., Brabham, P., Eaton, G., McCarroll, D. 1997. Glaciotectonized quaternary sediments at Dinas Dinlle, Gwynedd, North Wales, and their bearing on the style of deglaciation in the Eastern Irish Sea. Quaternary Science Reviews 16, 109-127.

Hiemstra, J.F., Rijsdijk, K.F., Evans, D.J.A., van der Meer, J.J.M. 2005. Integrated micro- and macro-scale analyses of Last Glacial Maximum Irish Sea diamicts from Abermaw and Treath y Mwnt, Wales, UK. Boreas 34, 61-74.

Hoffmann, K., Piotrowski, J.A. 2001. Till mélange at Amsdorf, central Germany: sediment erosion, transport and deposition in a complex, soft-bedded glacial system. Sedimentary Geology 140, 215-234.

Hoeoke, R. LeB., Hanson, B., Iverson, N.R., Jansson, P. and Fischer, U.H. 1997. Rheology of till beneath Storglaciären, Sweden. Journal of Glaciology 43, 172-179. 
Lee, J.R. 2001. Genesis and palaeogeographic significance of the Corton Diamicton (basal member of the North Sea Drift Formation), East Anglia, UK. Proceedings of the Geologist's Association 112, 43-67.

Lee, J.R. 2003. Early and Middle Pleistocene lithostratigraphy and palaeoenvironments in northern East Anglia, UK. Unpublished PhD Thesis, Royal Holloway University of London.

Lee, J.R., Rose, J., Riding, J.B., Hamblin, R.J.O., Moorlock, B.S.P. 2002. Testing the case for a Middle Pleistocene Scandinavian glaciation in Eastern England: evidence for a Scottish ice source for tills within the Corton Formation of East Anglia, UK. Boreas 31, 345-355.

Lee, J.R., Booth, S.J., Hamblin, R.J.O., Jarrow, A.M., Kessler, H., Moorlock, B.S.P., Morigi, A.N., Palmer, A., Pawley, S.J., Riding, J.B., Rose, J. 2004a. A new stratigraphy for the glacial deposits around Lowestoft, Great Yarmouth, North Walsham and Cromer, East Anglia, UK. Bulletin of the Geological Society of Norfolk 53, 3-60.

Lee, J.R., Rose, J., Hamblin, R.J.O., Moorlock, B.S.P. 2004b. Dating the earliest lowland glaciation of eastern England: a pre-MIS 12 early Middle Pleistocene Happisburgh Glaciation. Quaternary Science Review 23, 1551-1566.

Lee, J.R., Rose, J., Candy, I., Barendregt, R.W. 2006. Sea-level changes, river activity, soil development and glaciation around the western margins of the southern North Sea Basin during the Early and early Middle Pleistocene: evidence from Pakefield, Suffolk, UK. Journal of Quaternary Science 21, 155-179.

Lee, J.R., Phillips, E.R. 2008. Progressive soft sediment deformation within a subglacial shear zone - a hybrid mosaic-pervasive deformation model for Middle Pleistocene glaciotectonised sediments from Eastern England. Quaternary Science Reviews 27, 1350-1362.

Licciardi, J.M., Clark, P.U., Jenson, J.W., MacAyeal, D.R. 1998. Deglaciation of a softbedded Laurentide Ice Sheet. Quaternary Science Reviews 17, 427-448. 
Lunkka, 1988. Sedimentation and deformation of the North Sea Drift Formation in the Happisburgh area, north Norfolk. In Croot, D. (Ed). Glaciotectonics: Forms and Processes. Balkema, Rotterdam, 109-122.

Lunkka, J.P. 1994. Sedimentation and lithostratigraphy of the North Sea Drift and Lowestoft Till Formations in the coastal cliffs of northeast Norfolk, England. Journal of Quaternary Science 9, 209-233.

McCarroll, D., Rijsdijk, K.F. 2003. Deformation styles as a key for interpreting glacial depositional environments. Journal of Quaternary Science 18, 473-489.

Menzies, J., van der Meer, J.J.M., Rose, J. 2006. Tills - as a glacial "tectomict", its internal architecture and the development of a "typing" method for till differentiation. Geomorphology 75, 172-200.

Mitchell, G.F., Penny, L.F., Shotton., F.W., West, R.G. 1973. A Correlation of Quaternary Deposits in the British Isles. Geological Society of London Special Report No.4, 99pp.

Nieuwland, D.A., Leutscher, J.H., Gast, J. 2000. Wedge equilibrium in fold-and-thrust belts: prediction of out-of-sequence thrusting based on sandbox experiments and natural examples. Geologie en Mijnbouw/Netherlands Journal of Geosciences 79, 81-91.

Passchier, C.W., Trouw, R.A.J. 1996. Microtectonics. Springer-Verlag, Berlin, Heidelberg, New York. pp 289.

Pawley, S.M. 2006. Quaternary Glaciations of north and west Norfolk. Unpublished PhD Thesis, University of London.

Pawley, S.M., Rose, J., Lee, J.R., Moorlock, B.S.P., Hamblin, R.J.O. 2004. Early and Middle Pleistocene sedimentology and lithostratigraphy of Weybourne, northeast Norfolk, England. Proceedings of the Geologists’ Association 115, 25-42. 
Pawley, S.M., Bailey, R.J., Rose, J., Moorlock, B.S.P., Hamblin, R.J.O., Booth, S.J., Lee, J.R. 2008. Age limits on Middle Pleistocene glacial sediments from OSL dating, North Norfolk, UK. Quaternary Science Reviews, in press.

Pedersen, S.A.S. 1993. The glaciodynamic event and glaciodynamic sequence. In Aber, J.S. (Ed.) Glaciotectonics and Mapping Glacial Deposits. Canadian Plains Research Centre, University of Regina, Canada, 67-85.

Perrin, R.M.S., Rose, J., Davies, H. 1979. The distribution, variation and origins of preDevensian tills in eastern England. Philosophical Transactions of the Royal Society of London B287, 535-570.

Phillips, E.R., Merritt, J. 2008. Evidence for multiphase water-escape during rafting of shelly marine sediments at Clava, Inverness-shire, NE Scotland. Quaternary Science Reviews 27, 988-1011.

Phillips, E.R., Evans, D.J.A., Auton, C.A. 2002. Polyphase deformation at an oscillating ice margin following the Loch Lomond Readvance, central Scotland, UK. Sedimentary Geology $149,157-182$.

Phillips, E.R., Merritt, J., Auton, C., Golledge, N. 2007. Microstructures in subglacial and proglacial sediments: understanding faults, folds and fabrics, and the influence of water on the style of deformation. Quaternary Science Reviews 26, 1499-1528.

Preece, R.C., Parfitt, S.A. 2000. The Cromer Forest-bed Formation: new thoughts on an old problem. In Lewis, S.G., Whiteman, C.A., Preece, R.C. (Eds). The Quaternary of Norfolk and Suffolk, Field Guide. Quaternary Research Association, London, 1-27.

Preece, R.C., Parfitt, S.A., Bridgland, D.R., Lewis, S.G., Rowe, P.J., Atkinson, T.C., Candy, I., Debenham, N.C., Penkman, K.E.H., Rhodes, E.J., Schwenniger, J-L., Whittaker, J.E., Gleed-Owen, C. 2007. Terrestrial environments during MIS 11: evidence from the Palaeolithic site at West Stow, Suffolk, UK. Quaternary Science Reviews 26, 1236-1300. 
Preece, R.C., Parfitt, S.A. 2008. The Cromer Forest-bed Formation: some recent developments relating to early human occupation and lowland glaciation. In Candy, I., Lee, J.R., Harrison, A.M. (Eds). The Quaternary of northern East Anglia, Field Guide. Quaternary Research Association, London, in press.

Piotrowski, J.A., Kraus, A. 1997. Response of sediment to ice sheet loading in northwestern Germany: effective stresses and glacier bed stability. Journal of Glaciology 43, 495-502.

Piotrowski, J.A., Mickelson, D.M., Tulaczyk, S., Krzyszkowski, D., Junge, F.W., 2001. Were deforming subglacial beds beneath past ice sheet really widespread? Quaternary Science Reviews 86, 139-150.

Piotrowski, J.A., Larsen, N.K., Junge, F.W. 2004. Reflections on soft subglacial beds as a mosaic of deforming and stable spots. Quaternary Science Reviews 23, 993-1000.

Roberts, D.H., Hart, J.K. 2000. The Glacial Deposits of West Runton. In Lewis, S.H., Whiteman, C.A. and Preece, R.C. (Eds.). The Quaternary of Norfolk and Suffolk, Field Guide. Quaternary Research Association, London, 77-84.

Roberts, D.H., Hart, J.K. 2005. The deforming bed characteristics of a stratified till assemblage in north East Anglia, UK: investigating controls on sediment rheology and strain signatures. Quaternary Science Reviews 24, 123-140.

Rose, J., Moorlock, B.S.P., Hamblin, R.J.O. 2001. Pre-Anglian fluvial and coastal deposits in Eastern England: lithostratigraphy and palaeoenvironments. Quaternary International 79, 522.

Rijsdijk, K.F., Owen, G., Warren, W.P., McCarroll, D., van der Meer, J.J.M. 1999. Clastic dykes in over-consolidated tills: Evidence for subglacial hydrofracturing at Killiney Bay, eastern Ireland. Sedimentary Geology 129, 111-126.

Straw, A. 1983. Pre-Devensian glaciation of Lincolnshire (Eastern England) and adjacent areas. Quaternary Science Reviews 2, 239-260. 
Truffer, M., Harrison, W.D., Echelmeyer, K.A. 2000. Glacier motion dominated by processes deep in underlying till. Journal of Glaciology 46, 213-221.

van Gijssel, K. 1986. A lithostratigraphic and glacitectonic reconstruction of the Lamstedt Moriane, Lower Saxony (FRG). In van der Meer, J.J.M (Ed). Tills and Glaciotectonics. Balkema, Rotterdam.

van der Meer, J.J.M., Kjaer, K., Krüger, J. 1999. Subglacial water escape structures and till structure, Sléttjökull, Iceland. Journal of Quaternary Science 14, 191-415.

van der Meer, J.J.M., Menzies, J., Rose, J. 2003. Subglacial till: the deforming glacier bed. Quaternary Science Reviews 22, 1659-1685.

van de Wateren, F.M. 1986. Structural geology and sedimentology of the Dammer Berge push moraine, FRG. In van der Meer, J.J.M. (Ed). Tills and Glaciotectonics. Balkema, Rotterdam. 157-182

van der Wateren, F.M. 1995. Process of glaciotectonism. In Menzies, J. (Ed). Glacial Environments. Modern Glacial Environments: Processes, Dynamics and Sediments vol. 1. Butterworth-Heinemann, Oxford, 309-335.

van der Wateren, F.M., Kluiving, S.J., Bartek, L.R. 2000. Kinematic indicators of subglacial shearing. In Maltman, A.J., Hubbard, B., Hambrey, J.M. (Eds). Deformation of Glacial Materials. Geological Society, London, Special Publications 176, 259-291.

West, R.G. 1980. The pre-glacial Pleistocene of the Norfolk and Suffolk coasts. Cambridge University Press, Cambridge.

West, R.G., Donner, J.J. 1956. The glaciations of East Anglia and the East Midlands: a differentiation based on stone orientation measurements of the tills. Quarterly Journal of the Geological Society of London, 112, 146-184.

\section{Figures}


Fig. 1. Map showing the location of the West Runton to Sheringham section and Domains 1, 2 and 3 which are referred to within the text (a), and northern East Anglia (b).

Fig. 2. Detailed structural interpretation (Domain 1) of the eastern end of the West Runton to Sheringham section (see Fig. 1). The individual sections (a) to (e) cover the whole of Domain 1 with varying degrees of overlap between the sections. Approximate height of cliff face $=20$ to $25 \mathrm{~m}$.

Fig. 3. (a) Steep-sided, wedge-like feature ('till-prism', see text) composed of thrust-bound slices of BGTM and Marl. The planar thrust at the bottom of this thrust-related feature forms a prominent décollement surface separating the deformed sediments from the underlying WCF; (b) Convolute folding effecting the base of the RSGM and underlying Marl; (c) Large, steep-sided, wedge-like feature composed of thrust-bound slices of BGTM, HTM, WCF and Marl; (d) Well-bedded and cross-bedded sands and gravels of the RSGM stacked with thrust bound slices of Marl and BGTM; (e) Large-scale synform deforming thrust-stacked sequence of RSGM, BGTM and Marl; (f) Ductile shearing associated with thrusted base of a large, detached slab of Marl.

Fig. 4. Detailed structural interpretation (Domain 2) of part of the West Runton to Sheringham section (see Fig. 1). Approximate height of cliff face =c. $30 \mathrm{~m}$.

Fig. 5. Detailed structural interpretation (Domain 3) of the remainder of the West Runton to Sheringham section (see Fig. 1). The individual sections (a) to (h) cover the whole of Domain 3 with varying degrees of overlap between the sections. Approximate height of cliff face $=25$ to $35 \mathrm{~m}$.

Fig. 6. (a) Easterly verging antiform deforming a thrust-bound raft of well-bedded WCF; (b) Recumbent to very gently inclined, isoclinal fold deforming the S1 foliation present within the upper part of the HTM; (c) Highly attenuated intrafolial folds within the HTM; (d) Eyeshaped fold interference patterns developed within the HTM showing that it has undergone several phases of folding; (e) Layering/foliation within the HTM defined by chalk-rich layers. This foliation locally wraps around rounded to angular chalk clasts; (f) Low-angle extensional faults and extensional crenulation cleavage (ECC) deforming the layering/S1 foliation within the HTM. 
Fig. 7. (a) Irregular, highly deformed 'raft' of Walcott Till Member wrapped by the foliation within the HTM. Elongate, tail-like off shoots from the chalky Walcott Till extend into the foliation within the host HTM; (b) Recumbent to very gently inclined, isoclinal fold deforming the layering/S1 foliation present within the upper part of the BGTM; (c) Crenulation lineation (L2) developed in the hinge of a recumbent fold deforming the S1 foliation within the BGTM; (d) Recumbent folds cut by later thrusts within the BGTM showing that ductile folding was followed by at least one phase of E-directed brittle faulting; (e) Well-developed stretching lineation (L1) developed upon S1 foliation surfaces within the BGTM; (f) Asymmetrical, sheared lenses or augen of sand within the glacitectonic mélange facies of the BGTM.

Fig. 8. Lower hemisphere stereographic plots of structural data measured from the West Runton to Sheringham section. (a) Dip and dip azimuth of the S1 foliation within the HTM and BGTM; (b) Orientation of folds. Small symbols recumbent folds (F1/2), large symbols upright to steeply inclined folds (F2/3); (c) Orientation of the stretching lineation (L1) and crenulation lineation (L2).

Fig. 9. (a) Large subvertical water-escape conduit deforming the mélange facies of the BGTM; (b) Convolute-style synform deforming the foliation and early recumbent folds present within the BGTM and HTM. The core of the fold is composed of a deformed lens of sand and gravel possibly derived from the RSGM; (c) Folded, rotated lens/augen of pale coloured sand within the HTM. This sand lens may represent a detached (rootless) fold hinge; (d) Rootless fold deforming a steeply inclined lens or slab of well-bedded sand. This sand lens is lithologically similar to the RSGM and is entirely isolated within the HTM; (e) raft of WCF and chalk bedrock structurally overlying HTM. The contact between the basal sands and gravels of the WCG and underlying chalk is undeformed and represents an original erosive contact (see text for details). (f) Recumbent (F1/2) folding of a lenticular chalk raft enclosed within the HTM.

Fig. 10. A composite structural section through the complete West Runton to Sheringham section showing the variation in the style and intensity of deformation from east to west (see text for details). 
Fig. 11. Diagram showing the proposed proglacial to ice-marginal deformation model to explain the range of features observed at the eastern end of the West Runton to Sheringham section (Domains 1 and 2). (a) Cross-section. (b) Plan view showing how the possible development of small, sub-basins between the topographic ridges formed by the developing till-prisms.

Fig. 12. Diagram showing shear zone development and mélange generation within the subglacially deformed part (Domain 3) of the West Runton to Sheringham and the effects of 'open' and 'restricted' drainage at the front of the glacier on the down-ice extent of the shear zone.

Fig. 13. 3D block diagram showing the location of the sub-basins between the morainic ridges formed above the till-prisms developed in response to proglacial deformation.

Fig. 14. Schematic diagram showing the development of the West Runton glacial sequence and its wider regional context in eastern England and the southern North Sea: a) Ice advance of British ice from the west and northwest depositing the Kimmeridge-rich Lowestoft Till (black lines), and British North Sea advance from the north depositing the Walcott Till; b) Wastage of the British North Sea ice, creation of an ice marginal area over northeast Norfolk (stippled area) and deposition of the Bacton Green Till as a thick sequence of subaqueous debris flow; c) Retreat of British North Sea ice to the north, British ice advance west and north-westwards across north Norfolk depositing the Weybourne Town Till.

Fig. 15. Diagram showing the proposed generalised model of progressive proglacial to subglacial deformation based upon the features observed at West Runton to Sheringham.

\section{Tables}

Table 1. Lower and lower Mid-Pleistocene stratigraphy of northern East Anglia with particular reference to units that crop-out within the West Runton - Sheringham area of study shown in bold (modified from Lee et al., 2004a; Pawley et al., 2004).

\begin{tabular}{|c|c|c|}
\hline $\begin{array}{l}\text { Lithostratigraphy } \\
\text { (Subgroup / Formation / Member) }\end{array}$ & Sediment & Environment \& Process \\
\hline \multicolumn{3}{|l|}{ Briton's Lane Formation } \\
\hline Briton's Lane Sand \& Gravel Member & Sands and gravels & Proglacial outwash \\
\hline Runton Sand \& Gravel Member & Sands and gravels & Proglacial outwash \\
\hline
\end{tabular}




\section{(RSGM)}

Sheringham Cliffs Formation

Weybourne Town Till Member

Very chalky diamicton

Sandy diamicton

Stratified silts and clays

Ivy Farm Laminated Member Marl Bed (MB)

Stratified marl

Glaciation - till

Glaciation - till

Glaciolacustrine

Glaciolacustrine

Mid-Pleistocene

Lowestoft Formation

Lowestoft Till Member

Walcott Till Member (WTM)

Chalky, clayey diamicton

Silty, clayey diamicton

Glaciation - till

Glaciation - till

Happisburgh Formation

Happisburgh Till Member (HTM)

Sandy, grey diamicton

Glaciation - till

Wroxham Crag Formation (WCF)

Mundesley Member (MM)

Sands and gravels

Shallow marine

lower Mid-Pleistocene

Cromer Forest-bed Formation

West Runton Freshwater Bed

Organic muds

Floodplain

Wroxham Crag Formation

Mundesley Member

Gravels, sands \& muds

Tidal, shallow marine

Lower Pleistocene

White Chalk Subgroup

White, flinty chalk

Deep marine

Upper Cretaceous 


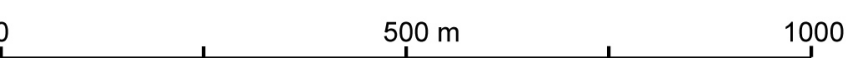

mum cliff line

$\uparrow$

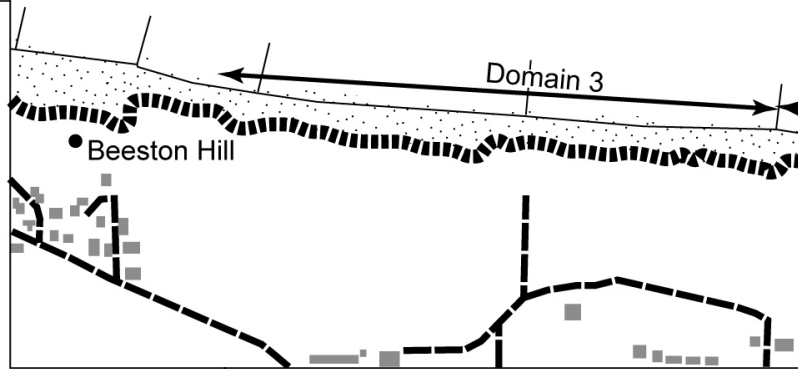

17

Domain 2
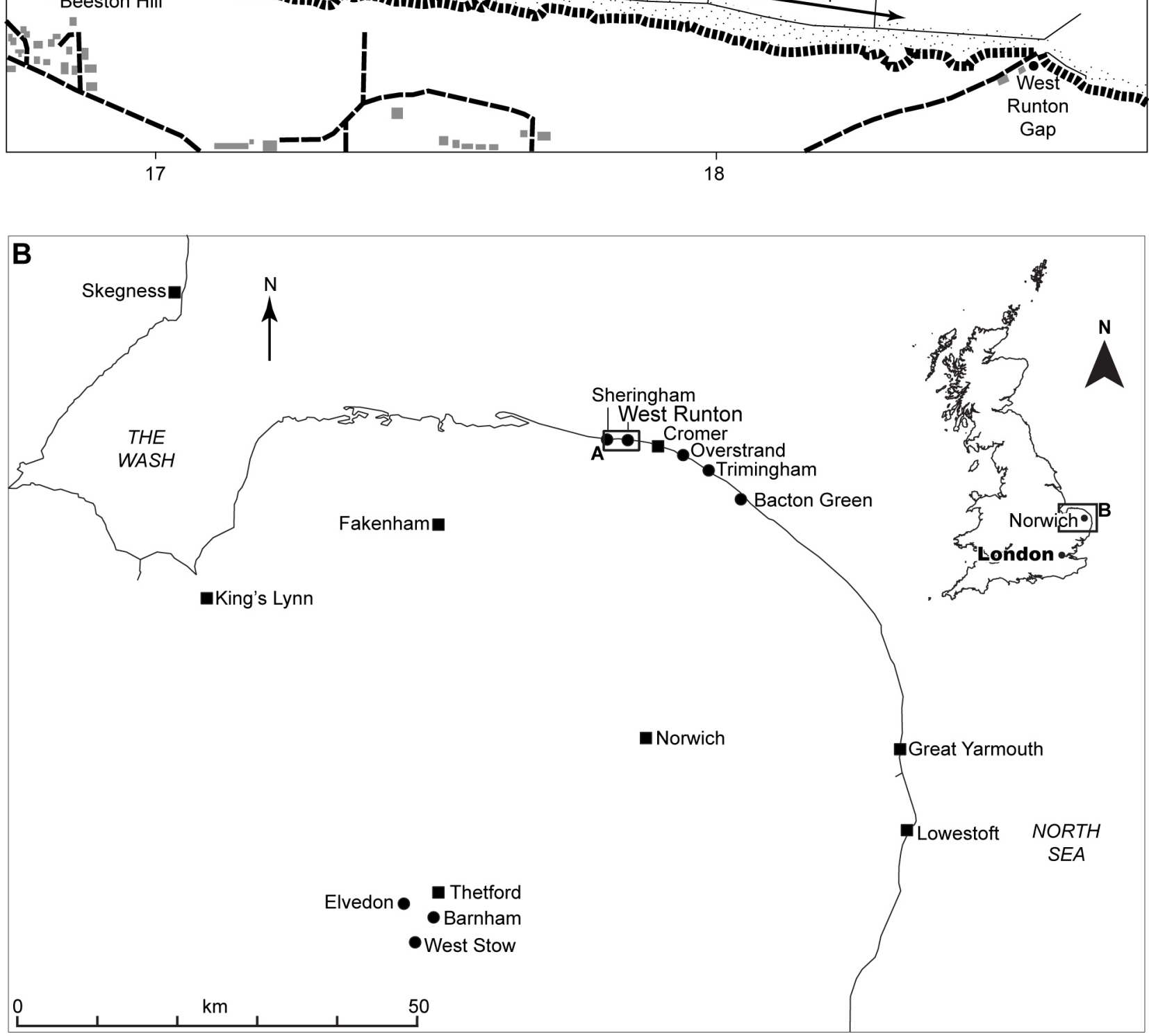

Figure 1 


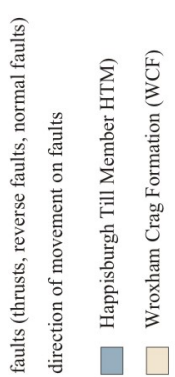

11 鹿

占

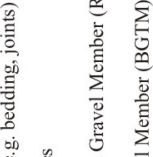

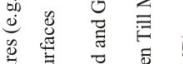

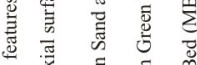

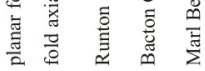
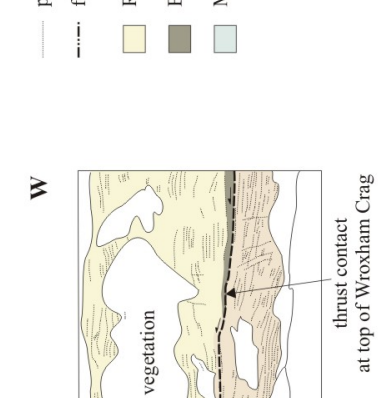

造

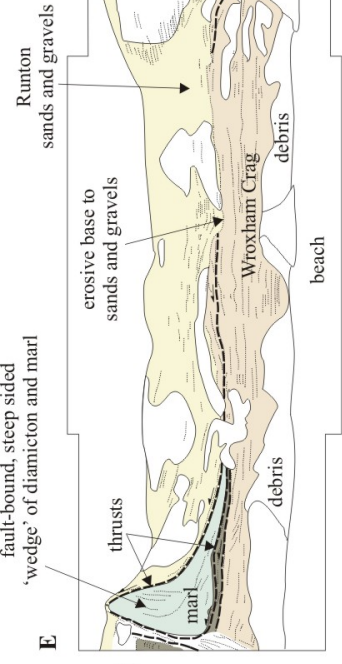

(2)
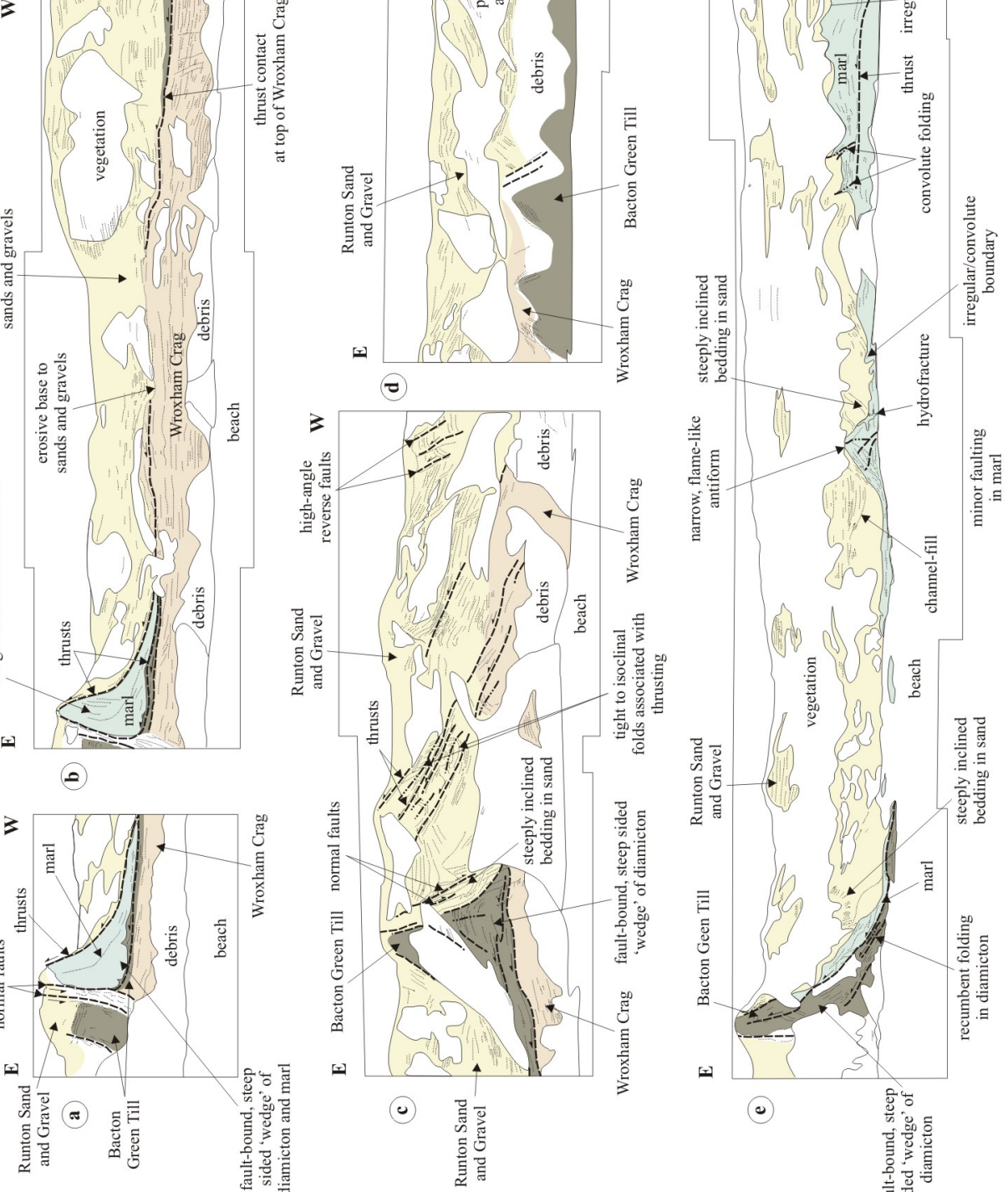
昱苛
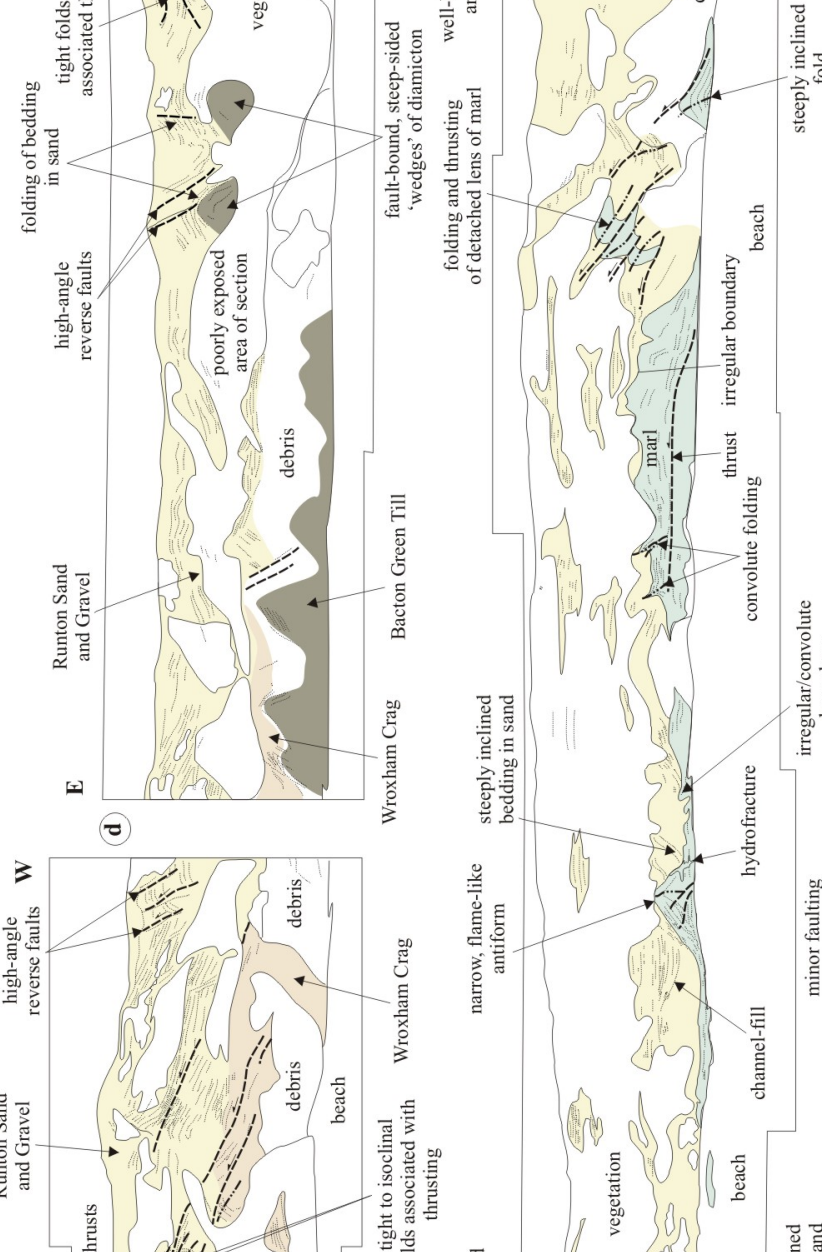
E normal fault

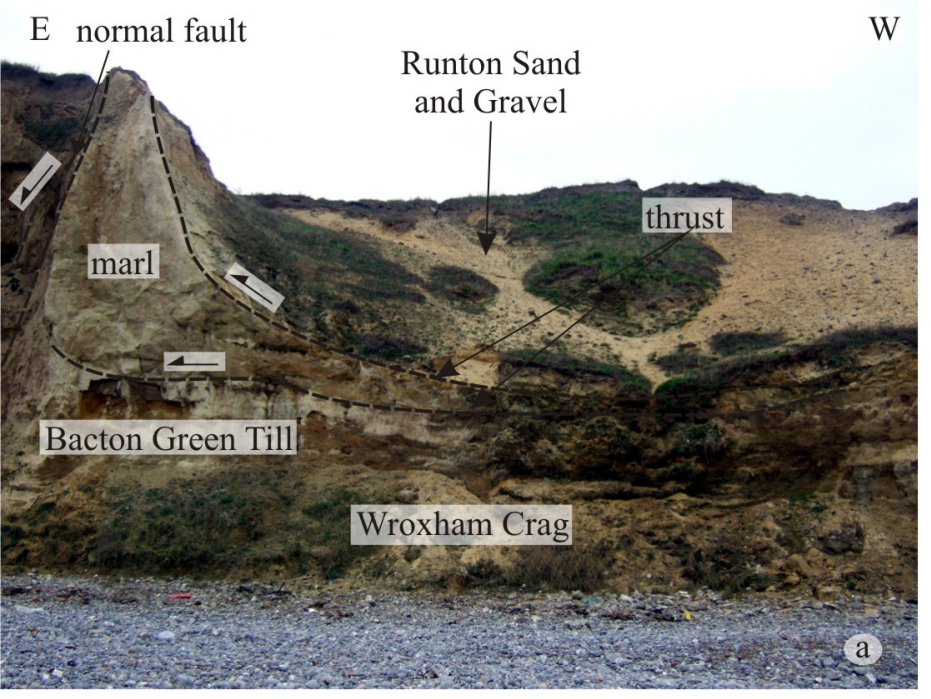

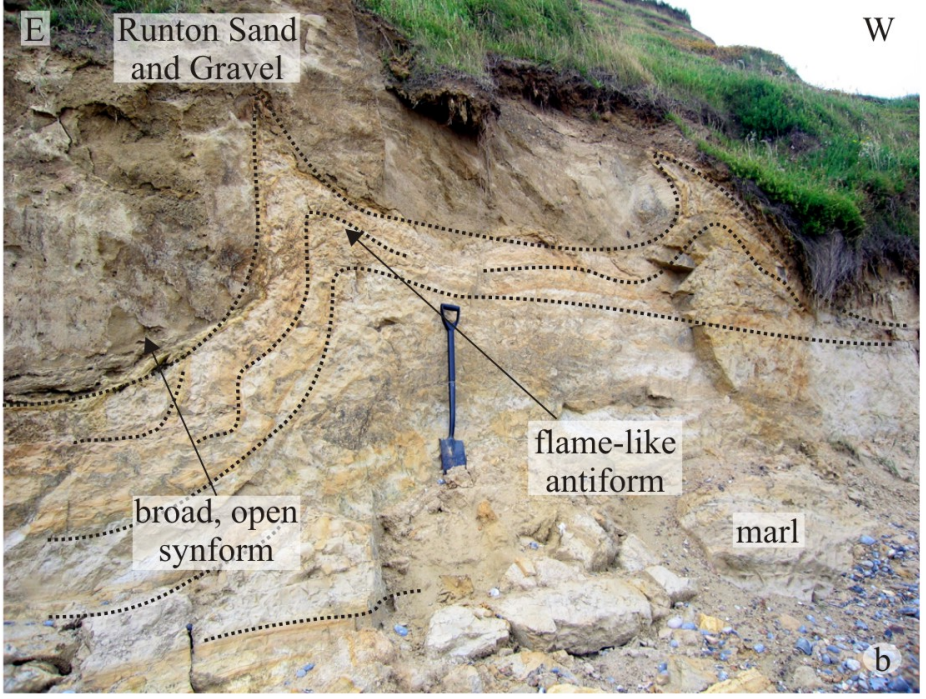

E Runton Sand and Gravel

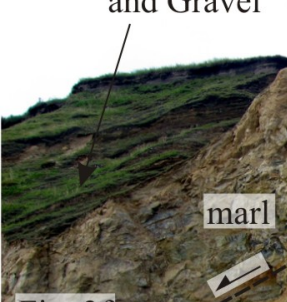

Fig. 3f

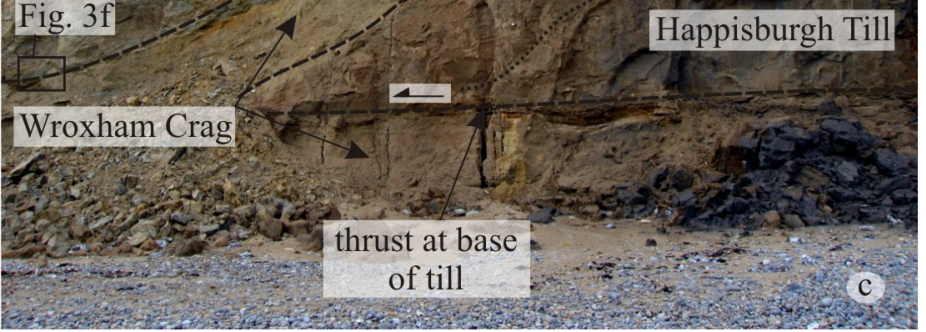

E Bacton Green Till

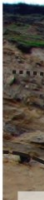

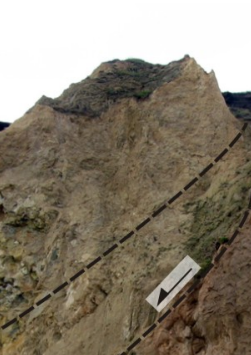

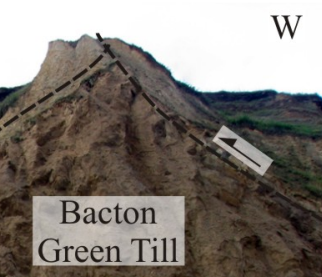

Happisburgh Till

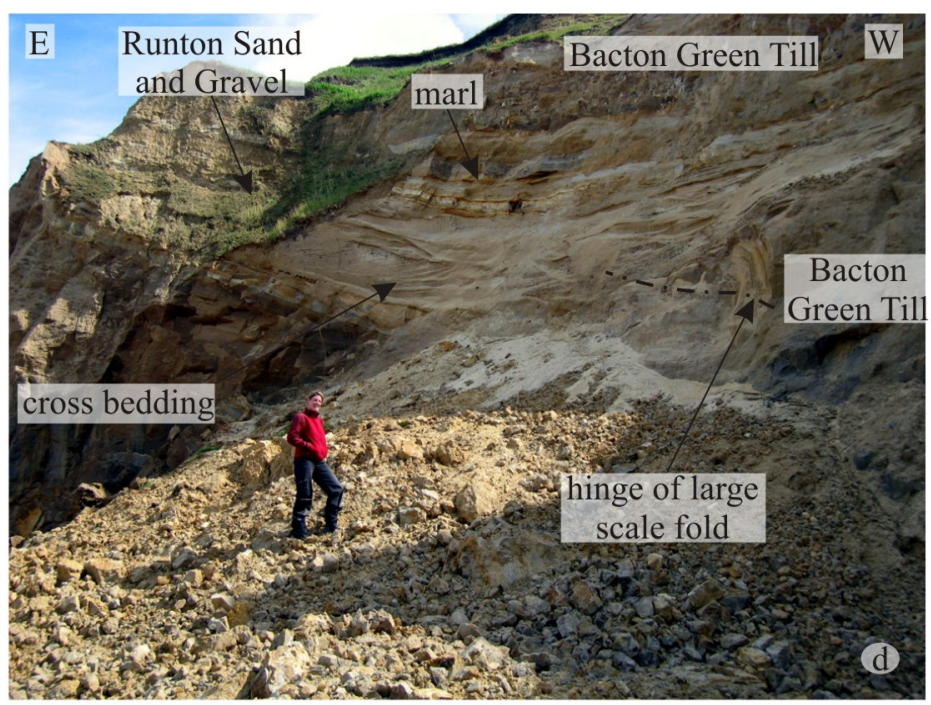

Figure 3.

Happisburgh Till

Bacton Green Til

Runton Sand

and Gravel :

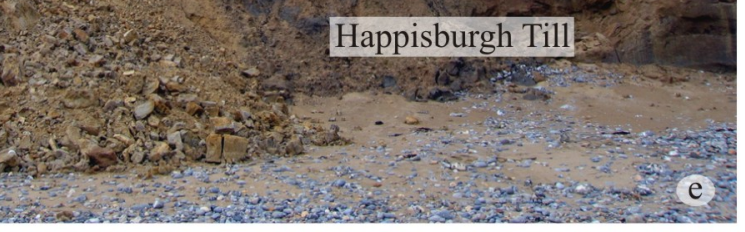

$\_$sense of displacement

-. - - - fold axial plane

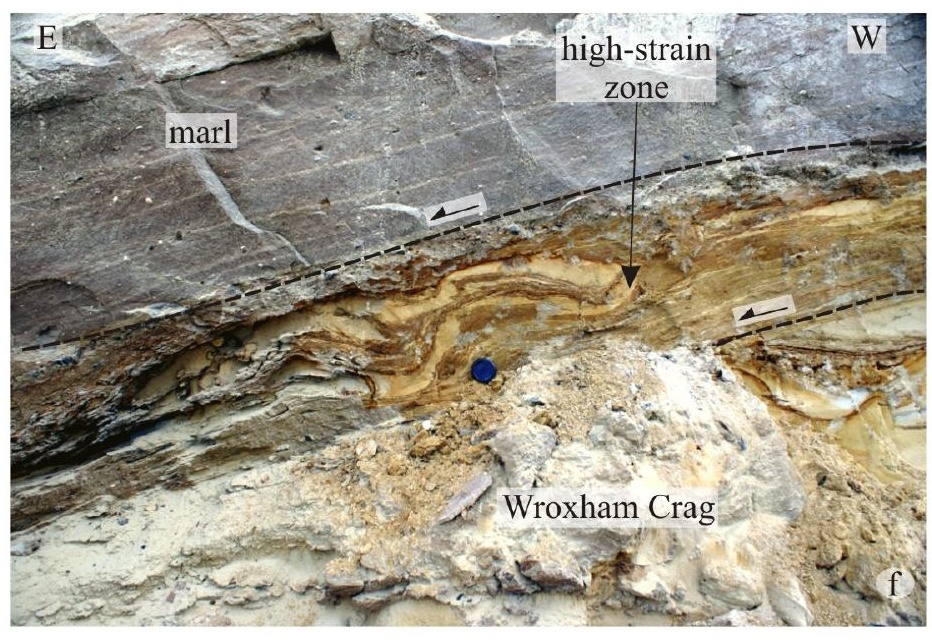

thrust 



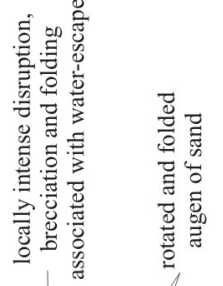

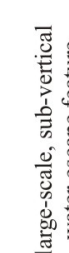
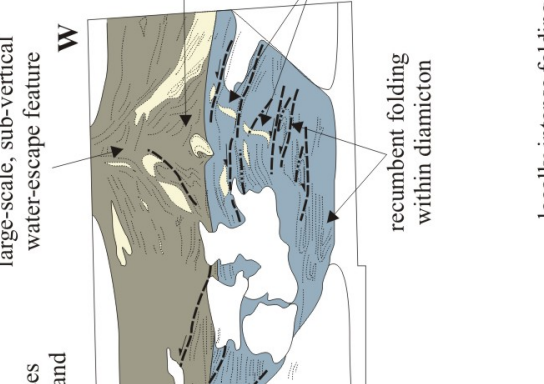

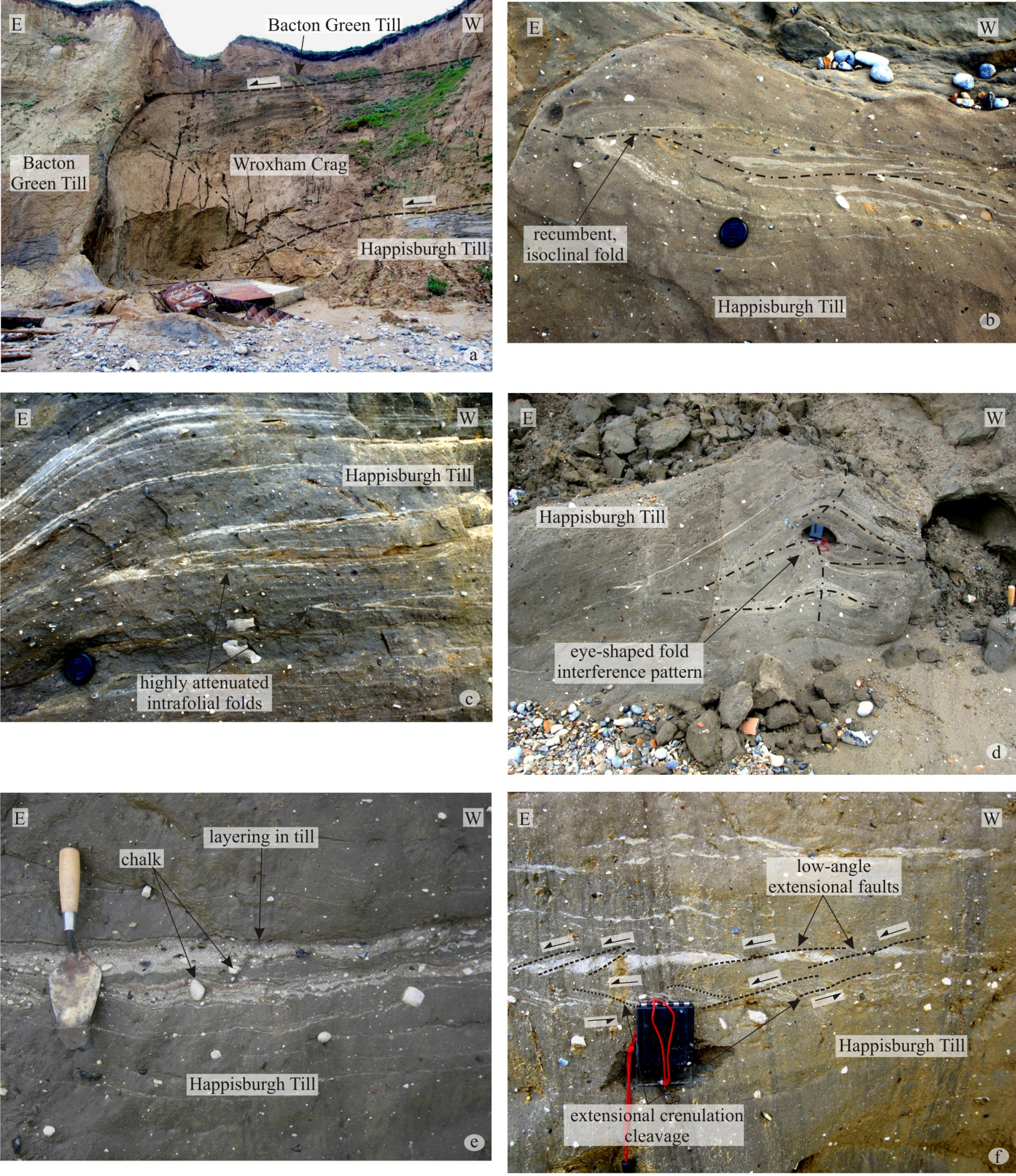

$\longleftarrow$ sense of displacement

-.-. - fold axial plane

thrust

Figure 6. 


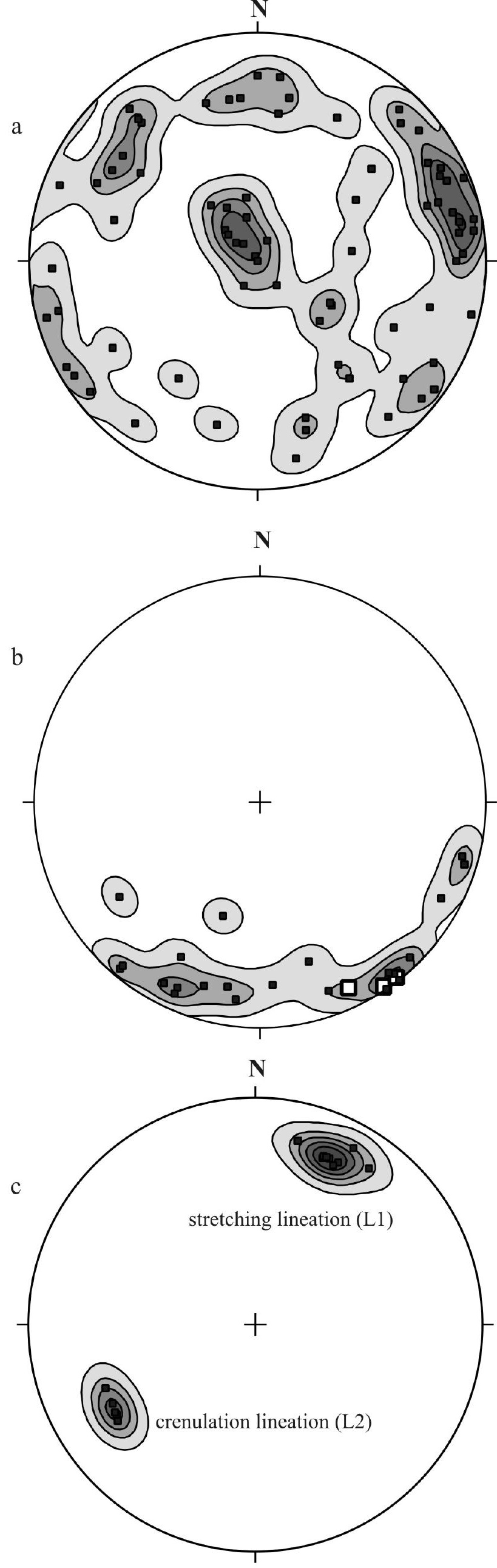

Figure 8. 
increasing size and complexity of till-prisms

increasing intensity of deformation

increasing topographic expression of till-prisms

$\mathbf{E}$ and greater influence of sediment dispersal patterns

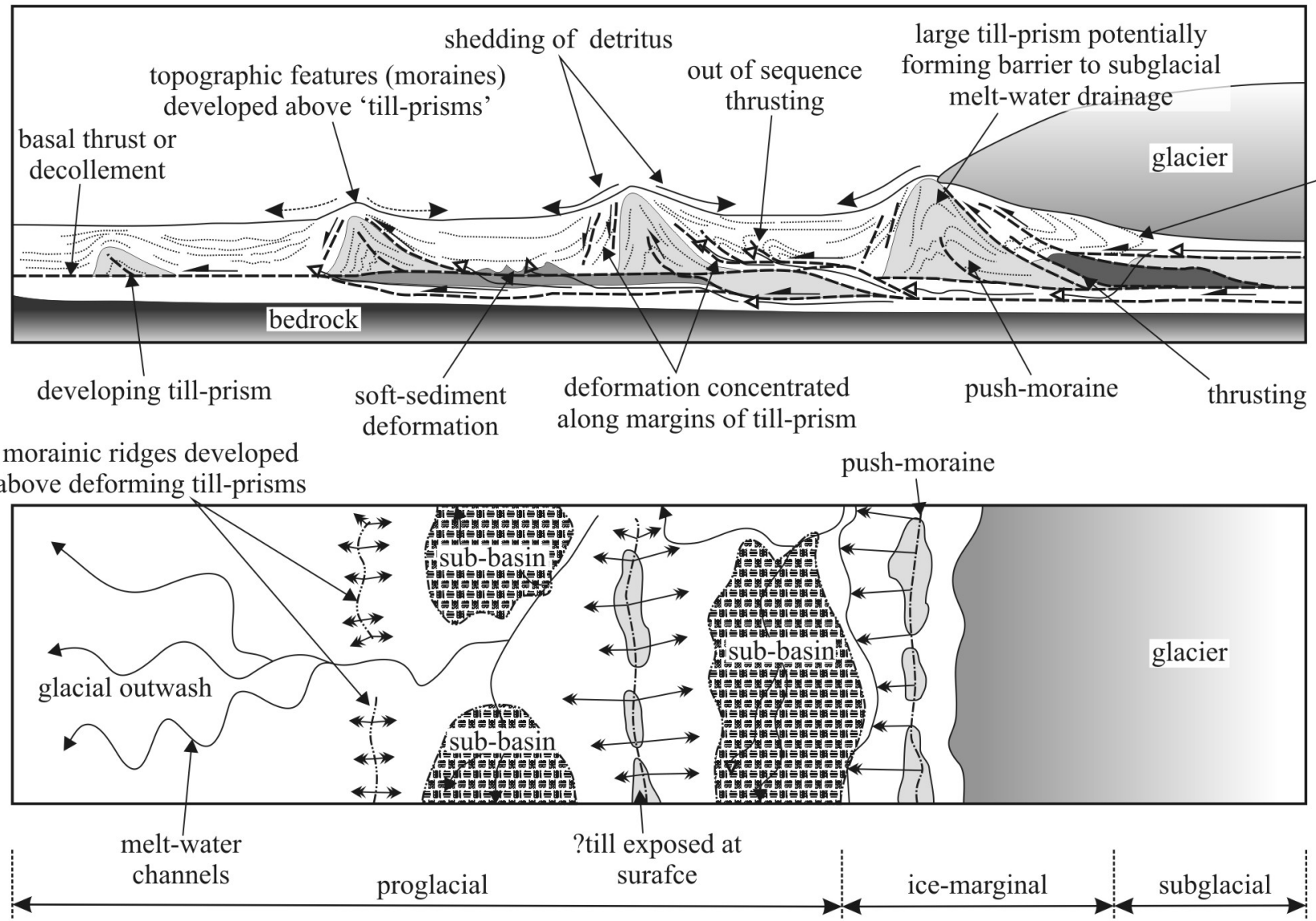

bedding -..- thrust

direction of movement direction of slope -...-. crest of morainic ridge ـ pathway followed by melt-water through the sediments melt-water channels

Bacton Green Till Member

Happisburgh Till Member

Marl Bed

Figure 11. 

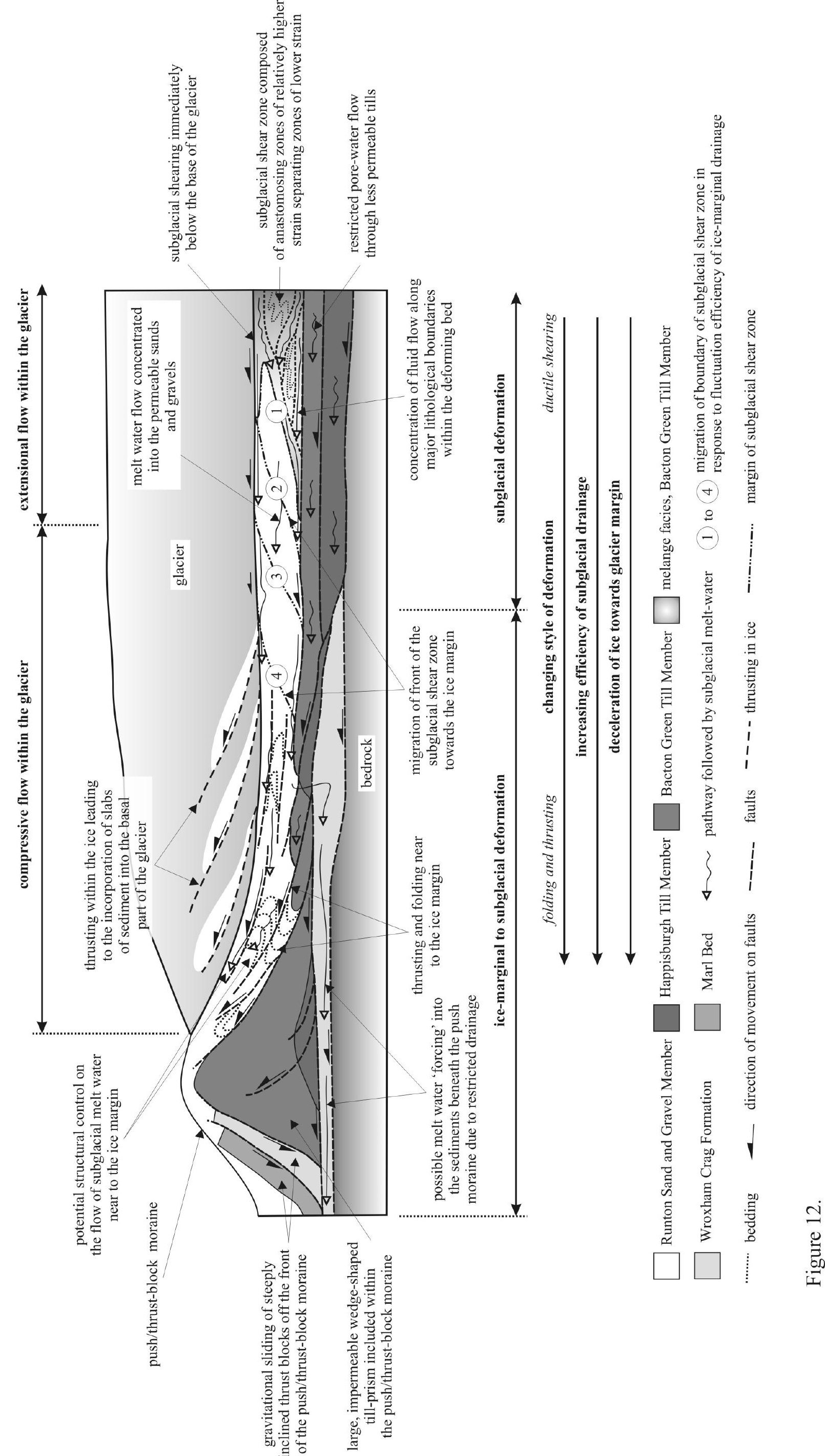


\section{supraglacial meltwater ice movement}

deposited adjacent to ice margin

emerging subglacial meltwater channel channel direction

small 'fore-land' sedimentary basins developed in front of the advancing glacier

moranic ridges developed

above tips of propagating thrusts

braided distributary channels

glacial outwash

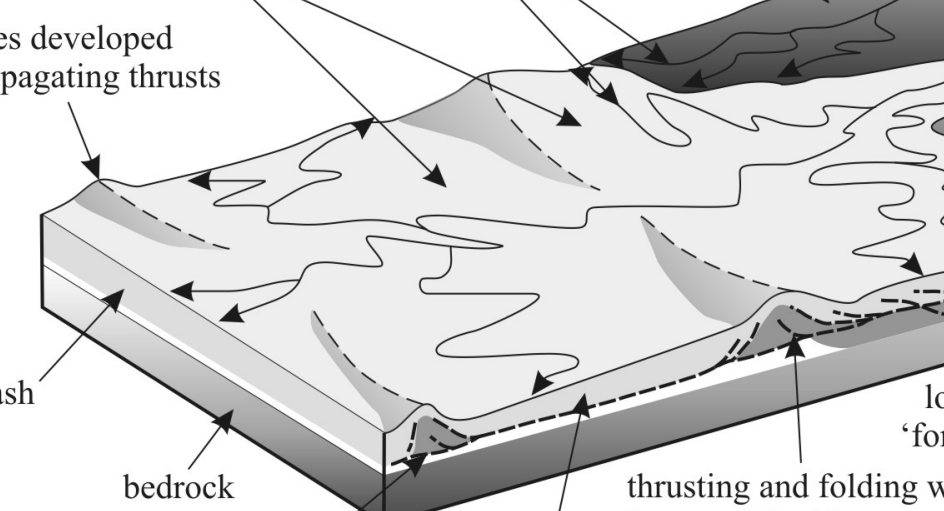

thrusting and folding within core of a morainic ridge representing the

thrusting and high-angle faulting associated with propagating tip of the main basal detachment

former position of the tip of the main basal detatchment undeformed sediment infill to small scale 'fore-land' sedimentary basin

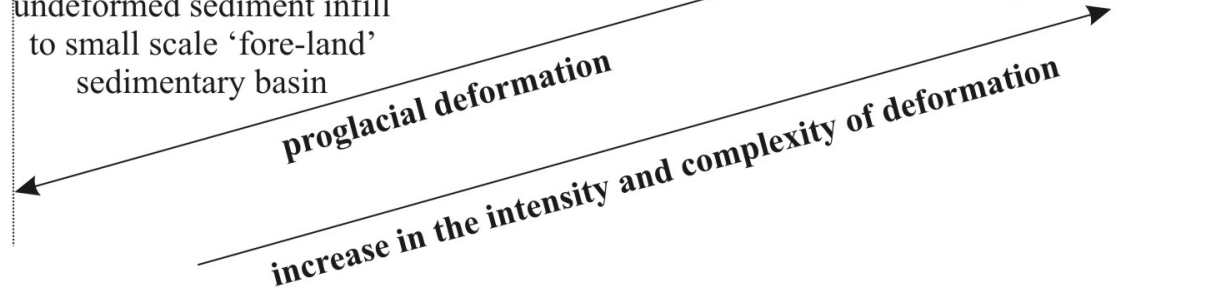

Figure 13. 

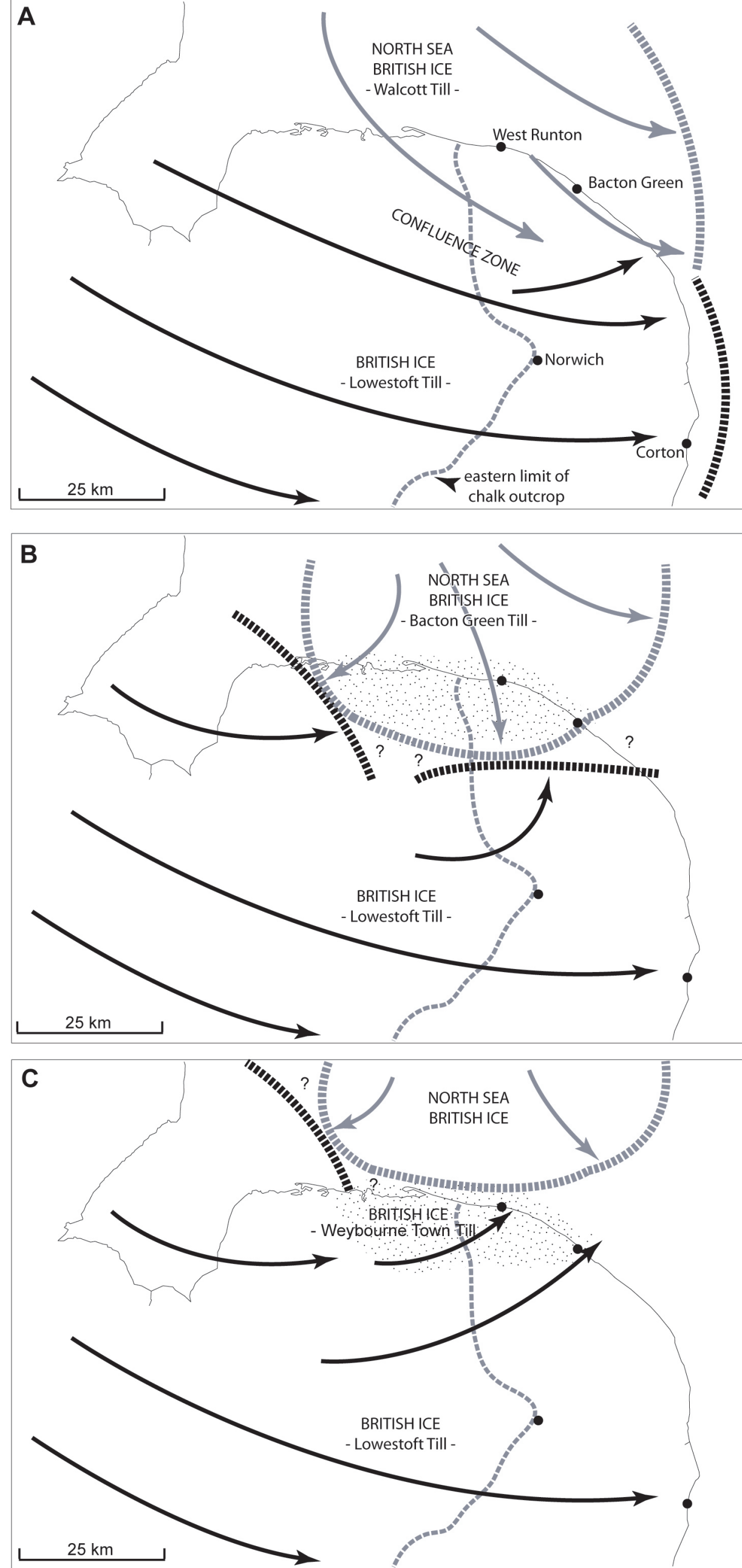
